\title{
ИОНЫ-КОМПЕНСАТОРЫ $\mathrm{H}^{+}$и $\mathrm{Li}^{+}$В СТРУКТУРНЫХ КАНАЛАХ КВАРЦА МЕСТОРОЖДЕНИЙ ЗОЛОТА ДАРАСУНСКОГО РУДНОГО ПОЛЯ (ВОСТОЧНОЕ ЗАБАЙКАЛЬЕ, РОССИЯ): ДАННЫЕ ЭЛЕКТРОННОГО ПАРАМАГНИТНОГО РЕЗОНАНСА
}

\author{
(C) 2019 г. Л.Т. Раков ${ }^{1, *}$, В. Ю. Прокофьев ${ }^{1}$, Л.Д. Зорина ${ }^{2}$ \\ ${ }^{1}$ Институт геологии рудных месторождений, петрографии, минералогии и геохимии РАН \\ Россия, 119017, Москва, Ж-17, Старомонетный пер., 35 \\ ${ }^{2}$ Институт геохимии им. А.П. Виноградова СО РАН \\ Россия, 664033, Иркутск, ул. Фаворского, 1 а \\ *E-mail: rakovlt@mail.ru \\ Поступила в редакцию 18.02.2016 г. \\ После доработки 13.04.2018 \\ Принята к публикации 17.05.2018
}

\begin{abstract}
Методом электронного парамагнитного резонанса исследованы состав и диффузионная подвижность ионов-компенсаторов в структурных каналах кварца месторождений золота Дарасун, Теремкинское и Талатуй Дарасунского рудного поля. Оценка свойств и особенностей распределения ионов в кварце основывалась на их способности участвовать в нейтрализации электрического заряда структурных дефектов, возникающих в минерале. В соответствии с этим состав ионов оценивался по соотношению концентраций Ті-центров с различными компенсаторами, а их подвижность определялась по скорости образования центров при радиационном облучении кварца. Проведенные исследования показали наличие в структурных каналах кварца золоторудных месторождений Дарасунского рудного поля двух основных видов ионов-компенсаторов - $\mathrm{H}^{+}$и $\mathrm{Li}^{+}$. Обнаружено, что диффузионная подвижность ионов $\mathrm{H}^{+}$в каналах на 1-2 порядка выше, чем $\mathrm{Li}^{+}$. Корреляционной связи состава ионов-компенсаторов в минерале с составом флюида не обнаружено.

Установлено различное соотношение между концентрациями ионов $\mathrm{H}^{+}$и $\mathrm{Li}^{+}$в структурных каналах кварца разных месторождений. Наибольшая концентрация ионов $\mathrm{H}^{+}$и наименьшая - ионов $\mathrm{Li}^{+}$регистрируется в кварце месторождения Дарасун, а обратное соотношение - в кварце месторождения Талатуй. Данный факт может объясняться перемещением газовой составляющей флюида в процессе рудоформирования.

Показано, что метод ЭПР может использоваться для количественной оценки степени динамической рекристаллизации кварца.

Ключевые слова: золоторудные месторождения Дарасун, Теремкинское и Талатуй Дарасунского рудного поля, золоторудный кварц, динамическая рекристаллизация, ионы-компенсаторы $\mathrm{H}^{+}$и $\mathrm{Li}^{+}$в структурных каналах кварца, диффузионная подвижность, оценка степени закрытости систем минералообразования, перемещение газовой кислотной фазы флюида при рудообразовании, метод электронного парамагнитного резонанса ЭПР.
\end{abstract}

DOI: $10.31857 /$ S0016-777061175-96

\section{ВВЕДЕНИЕ}

Условия минералообразования определяют многие особенности природного кварца, проявляющиеся в спектрах, полученных электронным парамагнитным резонансом (ЭПР), инфракрасной спектроскопией, люминесценцией и другими методами. Эти свойства весьма разнообразны, и каждое из них может иметь генетическое значение.

Важными качествами, которыми может характеризоваться кварц, являются состав ионовкомпенсаторов $\mathrm{Li}^{+}, \mathrm{Na}^{+}$и $\mathrm{H}^{+}$и их диффузионная подвижность в его структурных каналах. В кварце они играют стабилизирующую роль, поскольку обеспечивают электрическую нейтральность структурных дефектов. Ввиду этого, не может не вызывать интерес возможная связь состава и подвижности указанных ионов с условиями минералообразования.

К дефектам в кварце, требующим нейтрализации электрического заряда, относятся ионы $\mathrm{Ti}^{4+}$ и $\mathrm{Al}^{3+}$, изоморфно замещающие $\mathrm{Si}^{4+}$. Первые из них нуждаются в компенсации избыточного заряда, когда при радиационном облучении квар- 
ца захватывают электроны (Wright et al., 1963). Вторые, наоборот, первоначально имеют ионыкомпенсаторы, но после захвата дырок освобождаются от них. В обоих случаях образуются парамагнитные дефекты, известные как Ті- и $\mathrm{Al}-\mathrm{O}^{-}$-центры. При термическом воздействии на кварц эти центры могут распадаться, а возникающий при этом обмен ионами-компенсаторами между изоморфными ионами и другими ловушками осуществляется в обратном порядке.

Ранее был разработан подход к определению состава ионов-компенсаторов в структурных каналах и проведена оценка его генетического значения. Как отмечалось в работах (Гетманская, Раков, 1998; Раков, Шурига, 2009), распределение в структурных каналах $\mathrm{H}^{+}, \mathrm{Li}^{+}$и $\mathrm{Na}^{+}$может устанавливаться методом ЭПР по соотношению концентраций $\mathrm{Ti}(\mathrm{H})-$, $\mathrm{Ti}(\mathrm{Li})$ - и $\mathrm{Ti}(\mathrm{Na})$-центров, ионами-компенсаторами которых они являются. Эти соотношения использовались авторами для изучения условий образования месторождений редких элементов, вольфрама и других полезных ископаемых.

Данный подход позволяет оценивать состав наиболее подвижных ионов-компенсаторов в кварце. Они способны покидать ловушки и перемещаться в структурных каналах даже при относительно слабых радиационных или термических воздействиях на минерал. Подобные ловушки, очевидно, и образуют изоморфные ионы $\mathrm{Ti}^{4+}$, когда захватывают радиационные электроны. Их глубина определяется глубиной потенциальной ямы захваченных электронов, которая сравнительно невелика. Поэтому появление или распад Ті-центров всегда сопровождается диффузией ионов-компенсаторов. Особенности поведения подвижных ионов могут определяться целым рядом структурных факторов и служить тонким индикатором генезиса кварца.

Меньшей подвижностью характеризуются ионы-компенсаторы изоморфных ионов $\mathrm{Al}^{3+}$. Они начинают диффундировать при бо́льших дозах облучения и температурах отжига кварца, чем ионы-компенсаторы Ті-центров (Раков, 2007). Способ определения их состава описан в работе (Mackey, 1963). Он может отличаться от состава ионов-компенсаторов, локализованных на мелких ловушках, т. к. значительная часть изоморфного $\mathrm{Al}$ образуется при кристаллизации кварца, а изоморфный Ті возникает на стадии его динамической рекристаллизации (Раков, 2006).

Вопрос о диффузионной подвижности ионовкомпенсаторов в структурных каналах кварца в литературе освещен недостаточно. Хотя миграция щелочных ионов и протонов в процессе радиационного образования парамагнитных центров в кварце допускается многими авторами (Самойлович и др., 1972), условия и масштабы ее реализации пока изучены слабо. В работе (Раков, 1997) упоминалось о существовании двух групп кварца, отличающихся скоростью накопления $\mathrm{Al- \textrm {O } ^ { - } -}$, $\mathrm{Ti}(\mathrm{Li})-$, $\mathrm{Ge}(\mathrm{Li})-$ и других парамагнитных центров при радиационном облучении минерала. Эти различия были объяснены разной скоростью диффузии ионов-компенсаторов, принимающих участие в формировании центров.

Группа с высокой скоростью образования парамагнитных центров была названа "Урал”, а группа, в которой процессы их формирования протекали медленно, получила название "Алдан" (сокращенно "U” и “А” соответственно). Изучение динамики этих процессов показало, что в группе "U” формирование центров связано с процессом свободного заполнения ловушек электронами или дырками, а в группе "А" - описывается химической реакцией, ограниченной диффузией.

Выяснить природу медленной диффузии ионов-компенсаторов в кварце группы “А” до сих пор не удавалось. Дело в том, что данной группе принадлежит сравнительно небольшое количество образцов природного кварца. К настоящему времени можно назвать лишь несколько геологических объектов, на которых был обнаружен кварц группы “А”. К ним относятся месторождения горного хрусталя Ольховское (Южный Урал), Перекатное (Якутия) и некоторых других районов Алданской хрусталеносной провинции (Раков, 1999). Общее количество изученных образцов группы “А” оставалось слишком малым, чтобы делать обобщающие выводы.

Однако в последнее время появилась возможность значительно расширить их число. При исследовании кварца золоторудных месторождений Дарасунского рудного поля нами было обнаружено большое разнообразие его типов, часть которых могла относиться к группе “А”. Приобщение новых данных к полученным ранее результатам вселяет надежду решить вопрос о причинах появления двух описанных групп кварца, имеющих важное генетическое значение.

Настоящая работа посвящена изучению поведения подвижных ионов-компенсаторов в структурных каналах кварца. На примере образцов кварца из руд месторождений золота Дарасунского рудного поля рассмотрены факторы, определяющие состав и степень диффузионной подвижности этих ионов, а также их связь с условиями минералообразования.

\section{ИССЛЕДУЕМЫЙ МАТЕРИАЛ}

Основу исследованной коллекции составляли образцы поликристаллического кварца, отобранного из золоторудных месторождений Дарасунского рудного поля: Дарасун, Теремкинское и Талатуй. Подробное описание этих месторожде- 


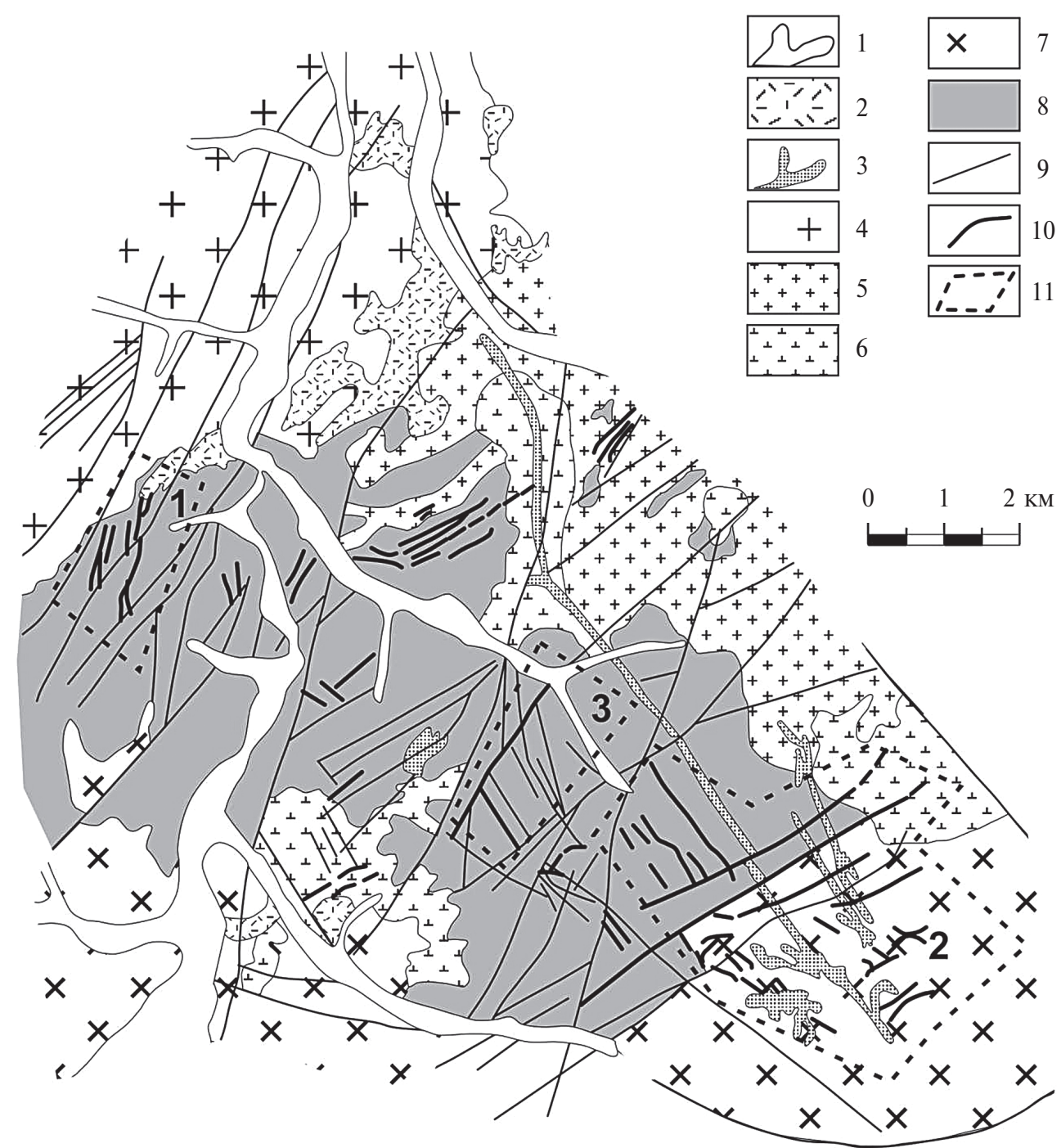

Фиг. 1. Геологическая карта Дарасунского рудного поля (по материалам Дарасунской геологоразведочной экспедиции).

1 - аллювиальные отложения; 2, 3 - амуджикано-сретенский комплекс $\left(\mathrm{J}_{2-3}\right): 2$ - вулканиты, 3 - субвулканические и дайковые тела порфировых пород: диоритовые порфириты, гранодиорит-порфиры, гранит-порфиры и др.; 4 - амананский комплекс (Т) - биотит-роговообманковые граниты, гранодиориты; 5, 6 - олекминский комплекс $\left(\mathrm{PZ}_{3}-\mathrm{MZ}_{1}\right): 5$ - биотитовые и лейкократовые граниты, 6 - сиениты, граносиениты, кварцевые сиениты; 7 - крестовский комплекс $\left(\mathrm{PZ}_{2}\right)$ - диориты, кварцевые диориты, гранодиориты; 8 - кручининский комплекс метаморфизованных габброидных пород $\left(\mathrm{PZ}_{1}\right)$ : гранитизированные габбро, амфиболиты, габбро-диориты, троктолиты; 9 - тектонические нарушения; 10 - рудные тела; 11 - месторождения: 1 - Талатуй, 2 - Дарасун, 3 - Теремкинское.

ний изложено в работах (Тимофеевский, 1972; Прокофьев, Зорина, 1996; Прокофьев и др., 2000; 2004; 2007, 2008; Prokofiev et al., 2010). Согласно результатам исследований, каждое из них представлено турмалин-кварц-сульфидной золоторудной минерализацией мезозойского возраста (Чернышев и др., 2014) локализованной среди магматических пород палеозойского возраста (фиг. 1).

Месторождение Талатуй образовано зонами прожилково-вкрапленной минерализации в габброидах кручининского комплекса $\left(\mathrm{PZ}_{1}\right)$. Основные минералы - пирит, халькопирит, магнетит, гематит, ильменит, самородное золото и шеелит. Жильные минералы - турмалин, эпидот, хлорит, кварц, карбонат, биотит, ортоклаз.

Теремкинское месторождение представляет собой серию сближенных пологозалегающих и крутопадающих золотоносных сульфидно-турмалин-кварцевых жил и минерализованных зон в габброидах кручининского комплекса $\left(\mathrm{PZ}_{1}\right)$. Сульфиды в рудах составляют в среднем около $20 \%$. Главные минералы - пирит, халькопирит, галенит, сфалерит, сульфосоли $\mathrm{Ag}, \mathrm{Bi}, \mathrm{Pb}$, самородное золото. Жильные минералы - кварц, турмалин, карбонаты. 
Месторождение Дарасун образовано серией протяженных крутопадающих золотосульфидных кварцевых жил и минерализованных зон, сконцентрированных вокруг субвулканической интрузии высококалиевых гранодиорит-порфиров амуджиканского комплекса. В краевых частях интрузива отмечаются трубообразные тела эксплозивных брекчий, сцементированных кварцем с турмалином и сульфидной минерализацией. Руды месторождения богаты сульфидами (40-60 об.\%). Основные минералы - пирит, арсенопирит, халькопирит, пирротин, блеклая руда, сфалерит, галенит, сульфосоли $\mathrm{Cu}, \mathrm{Ag}, \mathrm{As}, \mathrm{Bi}, \mathrm{Pb}$, сульфосоли $\mathrm{Bi}$, теллуриды и самородное золото. Жильные минералы - кварц, турмалин, карбонаты, гипс, ангидрит. Вмещающие породы - габброиды кручининского комплекса $\left(\mathrm{PZ}_{1}\right)$ и амфибол-биотитовые граниты крестовского комплекса $\left(\mathrm{Pz}_{2}\right)$.

Перечень всех отобранных для изучения образцов, их краткое описание и список присво- енных им лабораторных номеров приведены в табл. 1.

При исследовании природы возникновения групп кварца "U” и “A" использовались семь дополнительных образцов, принадлежность которых к данным группам была установлена ранее (Раков, 1997, 1999). Их краткое описание дано в табл. 2. В ней указаны старые шифры образцов, приведенные в статье (Раков, 1997), и новые лабораторные номера, используемые в настоящей работе. K группе "U” относились образцы U1 и U2 из месторождения жильного кварца Светлая речка (Средний Урал) и образцы горного хрусталя U3 и U4 из месторождения Астафьевское (Южный Урал). Группа “А” была представлена кварцем из месторождения Ольховское (Южный Урал) (обр. А5, А6 и А7).

Дополнительные образцы использовались в качестве контрольных при оценке принадлежности исследуемого кварца к какой-либо из групп.

Таблица. 1. Описание образцов кварца месторождений золота Дарасунского рудного поля

\begin{tabular}{|c|c|c|c|}
\hline Шифр пробы & Местоположение & Описание & Лаб. № \\
\hline \multicolumn{4}{|c|}{ Месторождение Дарасун (жилы) } \\
\hline 75др85 & Ж. Разведочная, гор. 160 м & $\begin{array}{l}\text { Мощность жилы в раздувах до } 46 \text { см. В заль- } \\
\text { бандах кварц, пирит, арсенопирит, халькопирит, } \\
\text { в центральной части розовый карбонат, галенит, } \\
\text { сфалерит }\end{array}$ & 1 \\
\hline Д705 & Ж. Морозовская, гор. 310 м & Кварц с пиритом & 2 \\
\hline $115 / 05$ & Ж. Юго-Западная 1, гор. 717 м & Кварц с пиритом и сфалеритом & 3 \\
\hline 1141др86 & Ж. Лебедевская -II, гор. 260 м & $\begin{array}{l}\text { Крупнозернистый кварц. В центральной части } \\
\text { жилы гнезда крупнозернистого пирита, местами } \\
\text { турмалин. Вмещающие породы березитизированы }\end{array}$ & 4 \\
\hline 3908 & Ж. Пирротиновая, гор. 435 м & Кварц с арсенопиритом & 5 \\
\hline $119 / 05$ & Ж. Улыбка, гор. 717 м & Кварц с пиритом и арсенопиритом & 6 \\
\hline 10др94 & Отвалы Юго-Западной шахты & $\begin{array}{l}\text { Кварц с халькопиритом и карбонатом, пирит и } \\
\text { галенит в единичных зернах }\end{array}$ & 7 \\
\hline 1203др86 & Ж. Юбилейная, гор. 210 м & $\begin{array}{l}\text { Мощность жилы } 5 \text { см. Кварц с карбонатом } \\
\text { с вкрапленностью пирита и халькопирита }\end{array}$ & 8 \\
\hline $101 / 05$ & Ж. Юго-Западная 2, гор. 667 м & Кварц с пиритом & 9 \\
\hline 564/др85 & Ж. Лебедевская-II, гор. 109 м & $\begin{array}{l}\text { Центральная часть выполнена кварцем, в заль- } \\
\text { бандах срастание турмалина с кварцем и пири- } \\
\text { том. Вмещающие породы - граниты с кварц- } \\
\text { турмалиновой минерализацией }\end{array}$ & 10 \\
\hline 4074 & Ж. Пирротиновая, гор. 435 м & Кварц с турмалином & 11 \\
\hline ДВ10 & Ж. Главная, поверхность & Кварцевая жила с видимым золотом & 12 \\
\hline 1188др86 & Ж. Лебедевская-II, гор. 210 м & $\begin{array}{l}\text { Прожилки кварц-карбонат-пирит-турмалинового } \\
\text { состава и мощностью около } 1 \text { см в березитизиро- } \\
\text { ванном, окварцованном, карбонатизированном } \\
\text { гранодиорите }\end{array}$ & 13 \\
\hline 1273др86 & Ж. Юбилейная, гор. 210 м & $\begin{array}{l}\text { Жила мощностью около } 5 \text { см кварц-карбонатного } \\
\text { состава с вкрапленностью пирита и халькопирита }\end{array}$ & 14 \\
\hline
\end{tabular}


Таблица. 1. Продолжение

\begin{tabular}{|c|c|c|c|}
\hline Шифр пробы & Местоположение & Описание & Лаб. № \\
\hline 1139др85 & Ж. Лебедевская-II, гор. 260 м & $\begin{array}{l}\text { Жила мощностью 8-10 см, сложена турмалин- } \\
\text { пирит-кварцевой, пирит-халькопирит-кварцевой } \\
\text { и блеклорудно-галенит-сфалерит-карбонат-квар- } \\
\text { цевой ассоциациями. Вмещающая порода - бе- } \\
\text { резитизированный гранодиорит-порфир }\end{array}$ & 15 \\
\hline 3019 & Ж. 2 Электрическая, гор. 385 м & Кварц с карбонатом & 16 \\
\hline 931др & Ж. Лебедевская-II, гор. 210 м & $\begin{array}{l}\text { Турмалин-кварц-пирит- карбонатный прожилок } \\
\text { в измененном граните }\end{array}$ & 17 \\
\hline $36 / 01$ & Отвалы Юго-Западной шахты & Кварц поздний с блеклой рудой & 18 \\
\hline 5ВД/94 & Отвал Юго-Западной шахты & $\begin{array}{l}\text { Жила мощностью } 18 \text { см, сложена кварц- } \\
\text { пиритовым агрегатом с небольшим количеством } \\
\text { турмалина. Вмещающие породы - березиты } \\
\text { с обильной вкрапленностью пирита }\end{array}$ & 21 \\
\hline \multicolumn{4}{|c|}{ Месторождение Дарасун (брекчия) } \\
\hline $65 / 01$ & Юго-восточное тело брекчий & Кварц с пиритом и турмалином & 19 \\
\hline $72 / 07$ & Юго-восточное тело брекчий & Кварц с пиритом и турмалином & 20 \\
\hline \multicolumn{4}{|c|}{ Месторождение Теремкинское } \\
\hline 106 & Ж. Горняцкая, гор. 155 м & $\begin{array}{l}\text { Прожилки кварца с пиритом в слабо изменен- } \\
\text { ных габбро с зеркалами скольжения }\end{array}$ & 22 \\
\hline $\begin{array}{l}\text { 5/01(мол) } \\
\text { 5/01(прозр) }\end{array}$ & Жила № 2, гор. 205 м & $\begin{array}{l}\text { Кварц-турмалиновая жила с сульфидами и } \\
\text { золотом }\end{array}$ & $\begin{array}{l}23 \\
23 a\end{array}$ \\
\hline $422 \mathrm{~T} 82$ & Ж. Горняцкая, гор. 105 м & Кварц с турмалином и пиритом & 24 \\
\hline $1107 \mathrm{~T} 82$ & Ж. Горняцкая, гор. 305 м & $\begin{array}{l}\text { Жила карбонат-кварц-турмалин-пирит- } \\
\text { арсенопиритового состава. Вмещающие по- } \\
\text { роды - окварцованные, хлоритизированные, } \\
\text { плагиопорфиры с вкрапленностью и гнездами } \\
\text { сульфидов }\end{array}$ & 25 \\
\hline 14шт87 & Ж. Горняцкая, гор. 295 м & $\begin{array}{l}\text { Жила пирит-халькопирит-кварцевого состава } \\
\text { с примесью галенита и сульфосолей. Мощность } \\
\text { до } 10 \text { см. Вмещающая порода - интенсивно из- } \\
\text { мененное хлоритизированное габбро }\end{array}$ & 26 \\
\hline $1106 \mathrm{~T} 82$ & Ж. Горняцкая, гор. 305 м & $\begin{array}{l}\text { Кварц с пиритом и турмалином в окварцован- } \\
\text { ных мелкозернистых гранитах с вкрапленными } \\
\text { сульфидами }\end{array}$ & 27 \\
\hline $878 \mathrm{~T} 82$ & Ж. Горняцкая, гор. 155 м & $\begin{array}{l}\text { Карбонат-кварц-турмалин-пиритовая жила. Вме- } \\
\text { щающие породы - измененное габбро }\end{array}$ & 28 \\
\hline 2424шт82 & Ж. № 2, гор. 205 м & $\begin{array}{l}\text { Обломки кварца, сцементированного раздроблен- } \\
\text { ным хлоритизированным и эпидотизированным } \\
\text { габбро }\end{array}$ & 29 \\
\hline $571 \mathrm{~T} 82$ & Ж. Вера, гор. 205 м & $\begin{array}{l}\text { Кварц-карбонат-турмалин-сульфидная (пирит, } \\
\text { халькопирит, блеклые руды) жила с видимым } \\
\text { золотом }\end{array}$ & 30 \\
\hline $11 / 01$ & Жила № 2, гор. 205 м & $\begin{array}{l}\text { Кварц с пиритом, халькопиритом и сульфосоля- } \\
\text { ми висмута }\end{array}$ & 31 \\
\hline 724/шт87 & $\begin{array}{l}\text { Теремкинское рудное поле, по- } \\
\text { верхность, канава 70, вскрыва- } \\
\text { ющая Теремкинский разлом }\end{array}$ & $\begin{array}{l}\text { Массивный молочно-белый кварц с сульфидной } \\
\text { минерализацией }\end{array}$ & 32 \\
\hline 920 т82 & Ж. Горняцкая, гор. 205 м & $\begin{array}{l}\text { Жила кварца мощностью 3-10 см с пиритом, } \\
\text { халькопиритом, галенитом, сфалеритом. }\end{array}$ & 33 \\
\hline $165 \mathrm{~T} 82$ & Ж. Горняцкая, гор. 105 м & Кварц с пиритом и халькопиритом & 34 \\
\hline
\end{tabular}


Таблица. 1. Окончание

\begin{tabular}{|c|c|c|c|}
\hline Шифр пробы & Местоположение & Описание & Лаб. № \\
\hline 1239 т82 & Ж. Горняцкая, гор. 255 м & Кварц-турмалин-пирит-халькопиритовая жила & 35 \\
\hline $\begin{array}{l}\text { 746т81(мол-пр) } \\
746 \mathrm{~T} 81 \text { (сахар) }\end{array}$ & Ж. Горняцкая, гор. 205 м & $\begin{array}{l}\text { Кварц-халькопирит-галенитовая жила в хлорити- } \\
\text { зированном габбро }\end{array}$ & $\begin{array}{l}36 \\
36 \mathrm{a}\end{array}$ \\
\hline \multicolumn{4}{|c|}{ Месторождение Талатуй } \\
\hline $33 / 10$ & Рудная зона 3, карьер № 2 & Кварц-пиритовый прожилок & 37 \\
\hline 58тл84 & $\begin{array}{l}\text { Шахта, гор. } 600 \text { м, рудная зона } \\
\text { № } 2\end{array}$ & $\begin{array}{l}\text { Кварцевый прожилок с пиритом в окварцован- } \\
\text { ном граните }\end{array}$ & 38 \\
\hline $154 / 05$ & $\begin{array}{l}\text { Рудная зона № 2, канава 9, } \\
\text { поверхность }\end{array}$ & Кварц с халькопиритом и борнитом & 39 \\
\hline $152 / 05$ & $\begin{array}{l}\text { Рудная зона № 2, канава 9, } \\
\text { поверхность }\end{array}$ & Кварц с пиритом и халькопиритом & 44 \\
\hline $15 / 10$ & Рудная зона № 2, карьер & Кварц с халькопиритом & 45 \\
\hline $15 / 10 \mathrm{a}$ & & Кварц с молибденитом & $45 \mathrm{a}$ \\
\hline 15/10в & & Кварц & $45 \mathrm{~B}$ \\
\hline $5 / 10$ & Рудная зона № 2, карьер & Кварц-турмалиновый прожилок & 43 \\
\hline $67 / 07$ & Рудная зона № 2, карьер & Кварцевая жила & 46 \\
\hline 4211 тл & $\begin{array}{l}\text { Шахта, гор. } 660 \text { м, рудная зона } \\
\text { № } 3\end{array}$ & $\begin{array}{l}\text { Кварцевые прожилки с пиритом, турмалином и } \\
\text { видимым золотом. }\end{array}$ & 40 \\
\hline $163 / 05$ & Рудная зона № 3, карьер & Кварц с пиритом и турмалином & 41 \\
\hline $30 / 01$ & Рудная зона № 3, карьер & Кварц-турмалиновая жила с пиритом & 42 \\
\hline $23 / 01$ & Рудная зона № 3, карьер & Поздний кварц-пиритовый прожилок & 47 \\
\hline $28 / 10$ & Рудная зона № 3, карьер & $\begin{array}{l}\text { Кварцевый прожилок с халькопиритом и } \\
\text { пиритом }\end{array}$ & 48 \\
\hline
\end{tabular}

Таблица. 2. Описание образцов кварца, принадлежность которых к группам “U” или “А” была установлена ранее (Раков, 1997; 1999)

\begin{tabular}{|c|c|c|}
\hline $\begin{array}{c}\text { Старый } \\
\text { шифр } \\
\text { образцов }\end{array}$ & Описание & $\begin{array}{l}\text { Новый } \\
\text { лаб. № }\end{array}$ \\
\hline 1 & $\begin{array}{l}\text { Молочно-белый кварц из месторождения жильного кварца Светлореченское } \\
\text { (Средний Урал), относящегося к рудной формации силекситов }\end{array}$ & U1 \\
\hline 2 & То же & U2 \\
\hline 3 & $\begin{array}{l}\text { Горный хрусталь из гидротермального кварцево-жильного месторождения Аста- } \\
\text { фьевское (Ю. Урал) }\end{array}$ & U3 \\
\hline 4 & То же & U4 \\
\hline 5 & $\begin{array}{l}\text { Кристаллический кварц цитриновой окраски из кварцево-жильного месторож- } \\
\text { дения Ольховское (Северный Урал), приуроченного к сланцам }\end{array}$ & A5 \\
\hline 6 & То же & A6 \\
\hline 7 & То же & A7 \\
\hline
\end{tabular}

\section{МЕТОДЫ И ПОДХОДЫ К ПРОВЕДЕНИЮ ИССЛЕДОВАНИЙ}

При постановке задачи предполагалось, что одним из факторов, определяющих состав ионов-компенсаторов в структурных каналах, может являться состав флюидных включений в кварце. Для проверки этой версии проводился анализ содержимого флюидных включений, результа- ты которого сравнивались с данными изучения примесей в кристаллической матрице минерала с целью выявления корреляционных связей.

В качестве другого фактора, оказывающего влияние на состав ионов-компенсаторов в кварце, рассматривалась степень дефектности кристаллической структуры минерала. Для выяснения ее роли отобранные образцы кварца 
исследовались методом ЭПР и растровой электронной микроскопии (РЭМ).

Как и в работах (Гетманская, Раков, 1998; Раков, Шурига, 2009), метод ЭПР привлекался для оценки состава подвижных ионов-компенсаторов в структурных каналах кварца. С этой целью проводили сравнение концентраций в минерале $\mathrm{Ti}(\mathrm{H})-$ и $\mathrm{Ti}(\mathrm{Li})$-центров. Соотношение их содержаний, как отмечалось выше, отражает статистическое распределение ионов-компенсаторов $\mathrm{H}^{+}$и $\mathrm{Li}^{+}$в структурных каналах. Вместе с тем, не исключалась возможность присутствия в исследуемых образцах $\mathrm{Ti}(\mathrm{Na})$-центров, которые встречаются в природном кварце при дефиците Li (Раков, Шурига, 2009).

Концентрации Ті-центров $\left(C_{\mathrm{Ti}}\right)$ измерялись в кварце после радиационного облучения дозой $10^{4}$ Гр. Она обеспечивает переход в парамагнитное состояние наибольшего количества структурного титана и является оптимальной для определения соотношения концентраций Ті-центров разных видов (Методические ..., 1991). Концентрация $\mathrm{Al}-\mathrm{O}^{-}$-центров, отвечающая всему изоморфному алюминию, $N_{\mathrm{Al}}$ оценивалась после радиационного облучения кварца дозой $D_{\max }=10^{6} \Gamma \mathrm{p}$.

Оценка скорости диффузии разных ионовкомпенсаторов в структурных каналах проводилась на основе данных о скорости накопления Ті-центров при радиационном облучении кварца. Считалось, что своевременная нейтрализация электрического заряда является важнейшим условием формирования центров (Раков, 2005). Если скорость миграции недостаточна, то ионы-компенсаторы просто "не успевают" стабилизировать зарождающиеся центры, и те распадаются. Раздельная регистрация Ті-центров с разными ионами-компенсаторами позволяет сравнить скорости диффузии ионов между собой.

Влияние дефектности кварца на скорость диффузии ионов-компенсаторов определялось по результатам изучения скорости накопления $\mathrm{Al}-\mathrm{O}^{-}$-центров. В этом подходе использовалась диффузия ионов $\mathrm{Li}^{+}$, являющихся главными компенсаторами электрического заряда изоморфных ионов $\mathrm{Al}^{3+}$. Скорость накопления $\mathrm{Al}-\mathrm{O}^{-}$-центров оценивалась параметром $\theta$, равным отношению $C_{\mathrm{Al}} / N_{\mathrm{Al}}$, где $C_{\mathrm{Al}}-$ концентрация $\mathrm{Al}-\mathrm{O}^{-}$-центров в кварце после радиационного облучения дозой $D=10^{4} \Gamma \mathrm{p}$.

Kроме $\mathrm{Al}-\mathrm{O}^{-}$-центров, располагающихся в зонах упорядоченной кристаллической структуры, рассматривались $\mathrm{Al}-\mathrm{X}$-центры, которые, по всей видимости, локализуются в дефектных областях кварца (Раков, 2007). На это указывают следующие обстоятельства.

Во-первых, Al-X-центры образуются исключительно в образцах низкотемпературного, не прошедшего динамическую рекристаллизацию кварца. Именно в таких образцах отмечаются наибольшие концентрации дефектных зон, характеризующиеся размытой картиной микродифракции, высоким содержанием неструктурных примесей и кремнекислородных вакансий (Раков и др., 2015; Раков и др., 2016). С другой стороны, не установлено ни одного случая, когда Al-X-центры в заметном количестве присутствовали в высокотемпературном кварце с упорядоченной кристаллической структурой. Эти закономерности прослеживаются для многих сотен образцов кварца разного генезиса, изученных авторами за длительный период.

Во-вторых, после прогрева минерала при температуре $T=900{ }^{\circ} \mathrm{C}$ концентрация Al-X-центров резко падает, хотя содержание $\mathrm{Al}^{-} \mathrm{O}^{-}$-центров увеличивается. Исчезновение Al-X-центров может быть вызвано преобразованием дефектных зон в зоны упорядоченной кристаллической структуры при температурном воздействии на кварц (Раков и др., 2016).

B-третьих, Al-X-центры наблюдаются в кварце из кристаллических пород и не замечены в кварце из осадочных отложений. Это свидетельствует о том, что они связаны с наиболее дефектными зернами кварца, разрушающимися при физическом и химическом выветривании минерала.

Разработка модели Al-X-центров затруднительна из-за наложения на его спектр ЭПР линий $\mathrm{Al}-\mathrm{O}^{-}$-центров, интенсивность которых на порядок выше. Однако можно предположить, что природа $\mathrm{Al}-\mathrm{X}$-центров связана с ионами $\mathrm{Al}^{3+}$, замещающими $\mathrm{Si}^{4+}$ и ассоциированными с кислородными вакансиями (Раков, 2007).

Концентрации $\mathrm{Al}-\mathrm{X}$-центров, отнесенные к значениям содержаний $\mathrm{Al}-\mathrm{O}^{-}$-центров $C_{\mathrm{Al}-\mathrm{X}} / C_{\mathrm{Al}}$, использовались в качестве показателя дефектности кристаллического строения кварца. Авторы полагали, что величина $C_{\mathrm{Al}-\mathrm{X}} / C_{\mathrm{Al}}$ соответствует соотношению объемов кварца, занятых областями дефектности и зонами относительно упорядоченной кристаллической структуры. Соотношение концентраций $\mathrm{Al}-\mathrm{X}$ - И $\mathrm{Al}-\mathrm{O}^{-}$-центров определяли в кварце, облученном дозой $10^{4}$ Гр.

Для более детального изучения взаимоотношения зон совершенной и дефектной структур в кварце и оценки степени его динамической рекристаллизации применялся метод РЭМ. Перед исследованием кварц подвергался предварительному травлению в плавиковой кислоте, вызывающему интенсивное растворение его дефектных областей (демпферных зон). Зоны совершенной кристаллической структуры (кристаллиты) при этом оставались практически не затронутыми воздействием кислоты. По взаимному расположению полостей растворенного кварца и сохранившихся кристаллитов судили о характере распределения в минерале зон совершенной и 
дефектной структур, отражающем степень его динамической рекристаллизации.

При анализе корреляционных связей между структурными показателями изучались графики их зависимости друг от друга. Ввиду сложности полученных закономерностей для их аппроксимации использовались эмпирические кривые.

\section{МЕТОДИКА АНАЛИЗА}

Микротермометрические исследования флюидных включений выполнялись в лаборатории геологии рудных месторождений ИГЕМ PAH с использованием микротермокамеры THMSG-600 фирмы Linkam (Англия). Индивидуальные флюидные включения изучались в двусторонне полированных пластинах толщиной 0.3-0.5 мм. После визуального просмотра и фотографирования препараты отклеивались от стекла, промывались этиловым спиртом и от них механически отделялись кусочки кварца с выбранными для исследований включениями. Концентрация солей для включений рассчитывалась по температуре плавления льда, либо по температуре растворения кристалла галита, с использованием данных из работы (Bodnar, Vityk, 1994). Солевой состав растворов определялся по температурам эвтектики (Борисенко, 1977). Давление оценивалось для гетерогенного флюида по сингенетичным существенно газовым и газо-жидким включениям как сумма давлений паров воды и давления $\mathrm{CO}_{2}$. Оценка концентраций солей и давлений водяного пара и углекислоты проводились с использованием программы FLINCOR (Brown, 1989).

Анализ состава флюидов из включений осуществлялся комплексом методов, включающим газовую и ионную хроматографию и ICP MS, и выполнялся из навесок 0.5 г фракции 0.5-0.25 мм в ЦНИГРИ (аналитик Ю.В. Васюта) по методике, опубликованной в работе (Кряжев и др., 2006). Предварительно во включениях той же навески определялось количество воды для расчета концентраций элементов в гидротермальном растворе. Анализировались также углекислота и метан, а после приготовления вытяжки в растворе определялись $\mathrm{Cl}, \mathrm{K}, \mathrm{Na}, \mathrm{Ca}, \mathrm{Mg}$ и все элементы, которые удалось обнаружить методом ICP MS.

Исследование кварца методом ЭПР проводили с использованием поликристаллических образцов, измельченных до крупности менее 0.1 мм. Радиационное облучение кварца осуществляли электронами с энергией 7 МэВ на ускорителе УЭЛВ-10-10-С-70 Центра коллективного пользования физическими методами исследования в Институте физической химии и электрохимии им. А.Н.Фрумкина Российской Академии Наук (ИФХЭ РАН).
Спектры ЭПР снимались на спектрометре ER-420 (Bruker) с длиной волны электромагнитного излучения $\lambda=3$ см при температуре $T=77 K$ в ФГБУ “ВИМС". Их интенсивность оценивалась по амплитудам реперных линий, удобных для регистрации и не искаженных наложением посторонних сигналов. Для Ті-центров в качестве реперных были выбраны линии, соответствующие ориентации зерен кварца вдоль оси X симметрии этих центров (Вертц, Болтон, 1975). Реперной для $\mathrm{Al}-\mathrm{O}^{-}$-центров служила линия тонкой структуры, регистрируемая при наиболее высоком значении магнитного поля.

Количественное определение концентраций парамагнитных центров в исследуемых пробах кварца осуществлялось с помощью контрольных образцов с аттестованными значениями их содержаний. Исключение составили Al-X-центры, основная часть спектра ЭПР которых скрыта

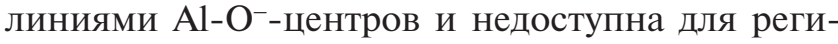
страции. По этой причине количественное измерение концентраций Al-X-центров в кварце невозможно, и использованная величина $C_{\mathrm{Al}-\mathrm{X}} / C_{\mathrm{Al}}$ является лишь их качественной характеристикой.

Образцы кварца, предназначенные для изучения методом РЭМ, имели форму пластин площадью $3-5 \mathrm{~cm}^{2}$ и толщиной около 4 мм. С одной стороны пластины полировались и обрабатывались раствором 30-процентной плавиковой кислоты при температуре $95^{\circ} \mathrm{C}$ в течение 1 часа. Эта сторона и явилась объектом наших исследований, которые выполнялись с помощью электронного микроскопа Tesla BS-301, укомплектованного энергодисперсионным спектрометром, в ФГБУ “ВИМС”.

\section{РЕЗУЛЬТАТЫ ИССЛЕДОВАНИЙ}

В ходе исследований был изучен состав флюидных включений в образцах кварца месторождений Дарасунского рудного поля, измерены концентрации парамагнитных дефектов, обусловленных изоморфными примесями $\mathrm{Al}$ и $\mathrm{Ti}$, определены состав и подвижность ионов-компенсаторов в структурных каналах минерала, изучены структурные особенности кварца каждого из месторождений.

Изучение флюидных включений. В кварце золотых руд месторождений Дарасунского рудного поля было обнаружено три типа флюидных включений: 1) трех- и многофазовые включения хлоридных рассолов; 2) двухфазовые флюидные включения водно-солевых растворов; и 3) газовые флюидные включения. Как правило, газовые включения 3 типа являются сингенетичными флюидным включениям типа 1 или типа 2 и свидетельствуют о гетерогенном состоянии рудообразующего флюида. Обобщенные данные 
Таблица 3. Данные исследования флюидных включений в кварце золотых руд

\begin{tabular}{l|c|c|c|c|c|c|c}
\hline \multicolumn{1}{c|}{ Месторождение } & $\begin{array}{c}\text { Количество } \\
\text { проб }\end{array}$ & $T,{ }^{\circ} \mathrm{C}$ & $C$, мас.\% & $\begin{array}{c}\mathrm{Na}, \\
\text { г/кг } \mathrm{H}_{2} \mathrm{O}\end{array}$ & $\begin{array}{c}\mathrm{Li}, \\
10^{-3} \text { г } / \mathrm{Kr}_{2} \mathrm{O}\end{array}$ & $\begin{array}{c}\mathrm{Ge}, \\
10^{-3} \text { г } / \mathrm{Kr}_{2} \mathrm{O}\end{array}$ & $\begin{array}{c}\mathrm{Ti}, \\
10^{-3} \text { г } / \mathrm{Kг}_{2} \mathrm{O}\end{array}$ \\
\hline Дарасун, жилы & 16 & $429-124$ & $44.8-0.7$ & $75.0-5.3$ & $213.8-0.8$ & $39.7-0.4$ & $565.0-0.6$ \\
Дарасун, брекчия & 1 & $618-216$ & $50.3-2.2$ & 27.4 & 17.7 & 5.3 & 150.4 \\
Теремкинское & 9 & $466-118$ & $41.0-1.2$ & $28.8-4.5$ & $90.7-6.1$ & $10.3-0.1$ & $32.4-2.7$ \\
Талатуй & 8 & $611-133$ & $56.3-0.4$ & $66.6-8.2$ & $70.1-0.7$ & $2.6-0.1$ & $37.8-1.1$ \\
\hline
\end{tabular}

термо- и криометрических исследований флюидных включений, а также химического состава флюидов из включений в кварце приведены в табл. 3.

На месторождении Дарасун рудоотложение происходило при температурах 429-124 ${ }^{\circ} \mathrm{C}$, соленость рудообразующего флюида изменялась от 44.8 до 0.7 мас.\% экв. $\mathrm{NaCl}$. Ранние минеральные ассоциации отлагались из гетерогенного флюида, газовая фаза которого содержала углекислоту, а концентрация солей жидкой фазы увеличивалась с падением температуры. Ниже $300^{\circ} \mathrm{C}$ происходила смена тенденций в изменении концентраций - уменьшение солености раствора с падением температуры. Рудообразующий флюид становится гомогенным. В это время происходит отложение основной массы самородного золота. Ниже $200{ }^{\circ} \mathrm{C}$ образуется пострудная кварц-кальцитовая ассоциация, завершающая гидротермальный процесс. В составе флюидов установлены (г/кг р-ра): $\mathrm{CO}_{2}$ (147-2.4), $\mathrm{CH}_{2}$ (10.4-0.12), а также $\mathrm{Na}, \mathrm{K}, \mathrm{Ca}, \mathrm{Mg}, \mathrm{Cl}, \mathrm{HCO}_{3}^{-}$ и повышенные концентрации ряда элементов, в том числе $\left(10^{-3}\right.$ г/кг $\left.\mathrm{H}_{2} \mathrm{O}\right)$ : $\mathrm{Li}(213.8-0.8)$, Ge (39.7-0.4) и Ті (565.0-0.6).

Кварц эксплозивных брекчий месторождения Дарасун (Прокофьев и др., 2008) кристаллизовался при температурах $618-216^{\circ} \mathrm{C}$, соленость минералообразующего флюида изменялась от 50.3 до 2.2 мас.\% экв. $\mathrm{NaCl}$. В составе флюида установлены (г/кг р-ра) $\mathrm{CO}_{2}$ (10.0), $\mathrm{CH}_{2}$ (1.8), и $\mathrm{Na}, \mathrm{K}, \mathrm{Ca}, \mathrm{Mg}, \mathrm{Cl}, \mathrm{HCO}_{3}^{-}$, а также повышенные концентрации ряда элементов, в том числе $\left(10^{-3}\right.$ г/кг $\left.\mathrm{H}_{2} \mathrm{O}\right)$ : $\mathrm{Li}$ (17.7), Ge (5.3) и Ti (150.4).

Ранние минералы Теремкинского месторождения отлагались из гетерогенного флюида при температурах $466-300{ }^{\circ} \mathrm{C}$ из растворов с концентрацией солей 41.0-1.2 мас.\% экв. $\mathrm{NaCl}$ на фоне падения температуры и давления. Ниже $290{ }^{\circ} \mathrm{C}$ флюид становится гомогенным. Продуктивный кварц формировался при температурах 297$216^{\circ} \mathrm{C}$ из гомогенного флюида, концентрации солей 26.4-4.2 мас.\% экв. $\mathrm{NaCl}$. Пострудный кварц отлагался при $195-118{ }^{\circ} \mathrm{C}$ из растворов с концентрацией солей 27.8-2.6 мас.\% экв. $\mathrm{NaCl}$. В составе растворов установлены (г/кг р-ра) $\mathrm{CO}_{2}$ 35.9-6.5, $\mathrm{CH}_{4}$ 3.5-0.05, и $\mathrm{Na}, \mathrm{K}, \mathrm{Ca}, \mathrm{Mg}$, $\mathrm{Cl}, \mathrm{HCO}_{3}^{-}$, а также повышенные концентрации ряда элементов, в том числе $\left(10^{-3}\right.$ г/кг $\left.\mathrm{H}_{2} \mathrm{O}\right): \mathrm{Li}$ (90.7-6.1), Ge (10.3-0.1) и Ti (32.4-2.7).

Руды месторождения Талатуй кристаллизовались при температурах $611-133^{\circ} \mathrm{C}$, соленость флюида изменялась от 56.3 до 0.4 мас.\% экв. $\mathrm{NaCl}$. Гетерогенный флюид наблюдался в интервале температур $611-310^{\circ} \mathrm{C}$. В составе флюидов обнаружены (г/кг р-ра) $\mathrm{CO}_{2} 49.8-5.9, \mathrm{CH}_{2}$ 0.35-0.02, и $\mathrm{Na}, \mathrm{K}, \mathrm{Ca}, \mathrm{Mg}, \mathrm{Cl}, \mathrm{HCO}_{3}^{-}$, а также повышенные концентрации ряда элементов, в том числе $\left(10^{-3}\right.$ г/кг $\left.\mathrm{H}_{2} \mathrm{O}\right)$ : $\mathrm{Li}(70.1-0.7)$, Ge (2.6-0.1) и Ті (37.8-1.1).

Геологические и минералогические данные позволяют объединить рудообразующий процесс на этих месторождениях в единую рудообразующую систему с изменяющимися в пространстве физико-химическими условиями. На всех месторождениях ранние ассоциации формировались из гетерогенного флюида. Наиболее высокие значения температур гомогенизации флюидных включений (618-611 $\left.{ }^{\circ} \mathrm{C}\right)$ и солености флюидов (56.3-50.3 мас.\%-экв. $\mathrm{NaCl)}$ обнаружены в кварце эксплозивных брекчий и руд месторождения Талатуй. Рудные жилы месторождений Теремкинское и Дарасун начали формироваться при более низких температурах (466-429 $\left.{ }^{\circ} \mathrm{C}\right)$ из флюидов с меньшей соленостиу (44.8- -41.0 мас.\% экв. $\mathrm{NaCl}$ и ниже).

Спектры ЭПР исследованных поликристаллических образиов. Фрагменты спектров ЭПРцентров, связанных с изоморфными примесями Ti и Al в кварце, представлены на фиг. 2 и 3. Рисунки демонстрируют способы измерений амплитуд реперных линий, использованные при оценке концентраций центров в порошкообразных пробах минерала.

По оси ординат на фиг. 2 и 3 отложены значения первой производной резонансного поглощения энергии электромагнитного излучения парамагнитными центрами, а по оси абсцисс - величины $g$-фактора, при которых это поглощение наблюдается. Значение $g$-фактора пропорционально соотношению частоты излучения и величины магнитного поля, отвечающему условию резонанса (Вертц, Болтон, 1975). Фрагменты приведенных спектров обусловлены поглощением энергии зернами кварца, ориентированными вдоль оси Х симметрии Ті-центров, 


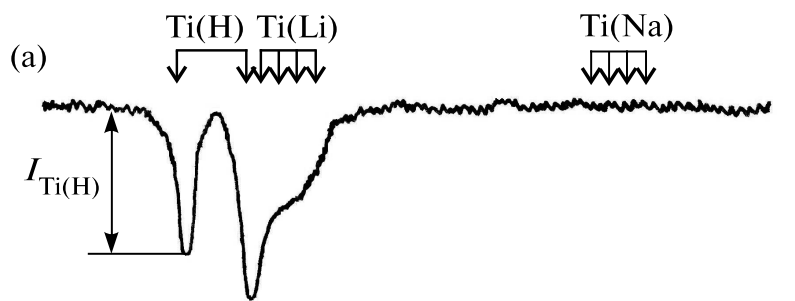

(б)

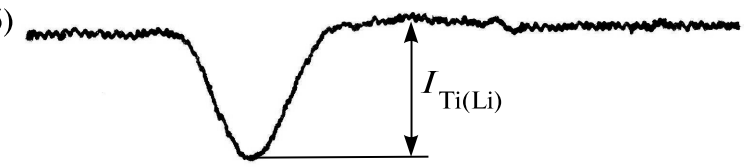

(B)

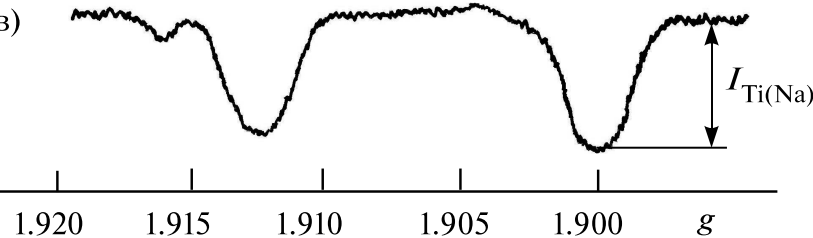

Фиг. 2. Линии ЭПР Ti(H)-, Ti(Li)- и Ti(Na)-центров в поликристаллическом кварце Дарасунского рудного поля, соответствующие $\mathrm{g}=\mathrm{g}_{\mathrm{X}}$ Спектры с интенсивными линиями $\mathrm{Ti}(\mathrm{H})$-центров (а) характерны для кварца месторождения Дарасун. Спектры, представленные сигналами $\mathrm{Ti}(\mathrm{Li})$-центров (б), типичны для образцов месторождения Талатуй. Линии $\mathrm{Ti}(\mathrm{Na})-$ центров (в) появляются в кварце брекчий месторождения Дарасун после отжига при $T=900^{\circ} \mathrm{C}$ (обр. 19). На спектрах иллюстрируется порядок измерения интенсивностей $I$ реперных линий $\mathrm{Ti}(\mathrm{H})-, \mathrm{Ti}(\mathrm{Li})-$ и $\mathrm{Ti}(\mathrm{Na})$-центров.

т. е. соответствуют $g=g_{\mathrm{X}}$. В спектре центров $\mathrm{Ti}(\mathrm{Li})$ и $\mathrm{Ti}(\mathrm{Na})$ эти фрагменты представляют собой слабовыраженные квартеты с фактором спектроскопического расщепления $g_{\mathrm{X}}=1.912$ и 1.900 , а в спектре центра $\mathrm{Ti}(\mathrm{H})$ - дублет с $\mathrm{g}_{\mathrm{X}}=1.915$ (Wright et al, 1963).

Установлено, что спектры ЭПР образцов кварца месторождений Дарасунского рудного поля содержат линии, отвечающие $\mathrm{Ti}(\mathrm{H})-$ и $\mathrm{Ti}(\mathrm{Li})$-центрам (фиг. 2а и 2б). При этом сигналов ЭПР $\mathrm{Ti}(\mathrm{Na})$-центров в исследованном кварце не обнаружено. Однако в образцах из юго-восточного тела брекчий месторождения Дарасун они появляются после отжига кварца при температуре $T=900^{\circ} \mathrm{C}$ (фиг. 2в).

Линии $\mathrm{Al}-\mathrm{O}^{-}$-центров присутствуют в спектрах всех образцов кварца (фиг. 3a), a Al-X-центров лишь в части из них (фиг. 3б). В большинстве образцов из месторождения Талатуй их сигнал настолько слаб, что не превышает порога обнаружения.

Кониентраиии иентров, связанных с изоморфными примесями Ті и Al. Значения концентраций $N_{\mathrm{Ti}}$ и $N_{\mathrm{Al}}$, обусловленных полными содержаниями изоморфных примесей $\mathrm{Ti}$ и $\mathrm{Al}$ в кварце Дарасунского рудного поля, даны

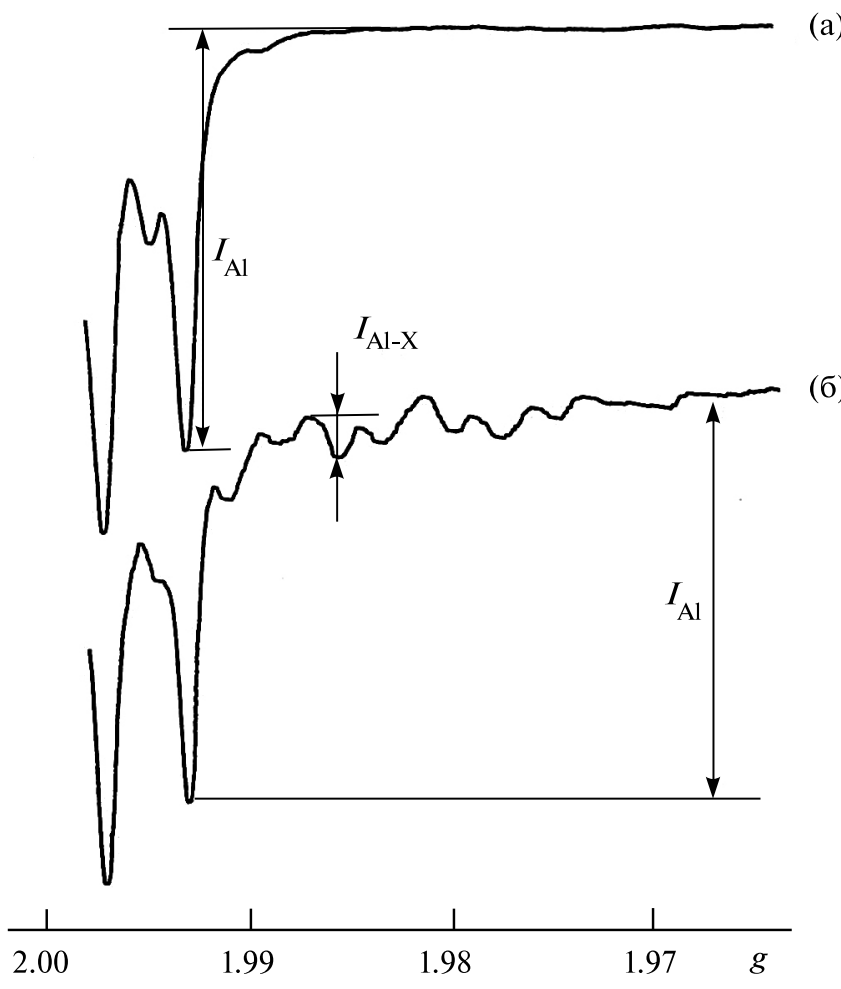

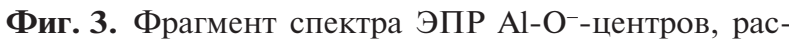
положенный в области сильных магнитных полей (a), и местоположение относительно него видимой части спектра Al-X-центров в поликристаллическом кварце месторождений Дарасунского рудного поля (б). Указаны интенсивности $I_{\mathrm{Al}}$ и $I_{\mathrm{Al}-\mathrm{X}}$ их реперных линий.

в табл. 4. Первое из них включает в себя сумму концентраций $\mathrm{Ti}(\mathrm{H})-$ и $\mathrm{Ti}(\mathrm{Li})$-центров, т. е. $N_{\mathrm{Ti}}=C_{\mathrm{Ti}(\mathrm{H})}+C_{\mathrm{Ti}(\mathrm{Li})}$.

В табл. 4 приведены величины отношений $C_{\mathrm{Al}-\mathrm{X}} / C_{\mathrm{Al}}$, являющиеся показателем уровня дефектности кварца и средние значения каждого из параметров по месторождению.

Относительные содержания подвижных ионов-компенсаторов в структурных каналах квариа. По соотношению концентраций $\mathrm{Ti}(\mathrm{H})$ - и $\mathrm{Ti}(\mathrm{Li})$-центров $\left(C_{\mathrm{Ti}(\mathrm{H})} / C_{\mathrm{Ti}(\mathrm{Li})}\right)$ оценивались относительные содержания подвижных ионов-компенсаторов $\mathrm{H}^{+}$и $\mathrm{Li}^{+}$в структурных каналах кварца. Результаты определений показывают, что величины отношений $C_{\mathrm{Ti}(\mathrm{H})} / C_{\mathrm{Ti}(\mathrm{Li})}$ в образцах кварца Дарасунского рудного поля варьируют в широких пределах (табл. 4).

Обнаружено, что средние значения $C_{\mathrm{Ti}(\mathrm{H})} / C_{\mathrm{Ti}(\mathrm{Li})}$ для каждого из месторождений неодинаковы. Для месторождения Дарасун оно превышает 2.2, для месторождения Теремкинское принимает значение 0.8 , а для месторождения Талатуй - ниже 0.13 (табл. 4).

При этом наблюдается уменьшение отношения $C_{\mathrm{Ti}(\mathrm{H})} / C_{\mathrm{Ti}(\mathrm{Li})}$ при росте содержания в кварце изоморфного титана. Графики зависимостей 
Таблица 4. Концентрации парамагнитных центров, связанных с изоморфными примесями Тi и $\mathrm{Al}$, и соотношения между ними в кварце месторождений золота Дарасунского рудного поля

\begin{tabular}{|c|c|c|c|c|c|c|c|c|c|c|c|c|c|}
\hline \multirow[b]{2}{*}{$\begin{array}{l}\stackrel{1}{2} \\
\dot{0} \\
\text { 品 }\end{array}$} & \multicolumn{4}{|c|}{$\mathbf{T i}$} & \multicolumn{2}{|c|}{ Al } & \multirow[b]{2}{*}{$\begin{array}{l}2 \\
2 \\
0 \\
0 \\
\end{array}$} & \multicolumn{4}{|c|}{$\mathbf{T i}$} & \multicolumn{2}{|c|}{ Al } \\
\hline & $\begin{array}{l}\stackrel{0}{0}=\frac{1}{2} \\
\underset{z}{z}=0\end{array}$ & 起 & ن & 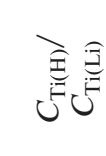 & 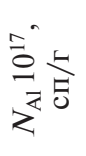 & 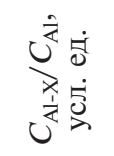 & & 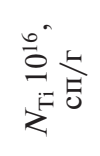 & 善窝 & 氖完 & 总总 & 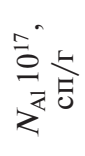 & 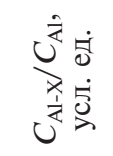 \\
\hline \multicolumn{7}{|c|}{ Месторождение Дарасун (жилы) } & 24 & $<0.1$ & $\mathrm{H} / \mathrm{O}$ & $\mathrm{H} / \mathrm{O}$ & $\mathrm{H} / \mathrm{o}$ & 4.2 & 0.095 \\
\hline 1 & 0.6 & 0.4 & 0.2 & 2 & 5.2 & 0.182 & 25 & 0.5 & 0.2 & 0.3 & 0.7 & 8.4 & 0.070 \\
\hline 2 & $<0.1$ & $<0.1$ & $<0.1$ & $\mathrm{H} / \mathrm{O}$ & 6.7 & 0.166 & 26 & 0.2 & 0.1 & 0.1 & 1.0 & 5.1 & 0.070 \\
\hline 3 & 0.4 & 0.4 & $<0.1$ & $>4$ & 4.1 & 0.156 & 27 & 0.3 & 0.1 & 0.2 & 0.5 & 5.3 & 0.067 \\
\hline 4 & 0.4 & 0.3 & 0.1 & 3 & 6.8 & 0.134 & 28 & 0.1 & 0.1 & $\mathrm{H} / \mathrm{o}$ & $\mathrm{H} / \mathrm{O}$ & 3.3 & 0.043 \\
\hline 5 & 0.9 & 0.5 & 0.4 & 13 & 4.4 & 0.125 & 29 & $<0.1$ & $\mathrm{H} / \mathrm{O}$ & $\mathrm{H} / \mathrm{o}$ & $\mathrm{H} / \mathrm{O}$ & 4.6 & 0.034 \\
\hline 6 & 0.5 & 0.5 & $<0.1$ & $>5$ & 3.4 & 0 & 30 & 0.7 & 0.3 & 0.4 & 0.8 & 7.0 & 0.025 \\
\hline 7 & 0.5 & 0.3 & 0 & 15 & 5.4 & 0.109 & 31 & 0.4 & 0.1 & 0.3 & 0.3 & 7.9 & 0.018 \\
\hline 8 & 0.2 & 02 & $\begin{array}{r}0.2 \\
<0.1\end{array}$ & 1.0 & 5.0 & 0.100 & 32 & 0.5 & 0.2 & 0.3 & 0.7 & 8.2 & 0.015 \\
\hline 9 & 05 & 0.2 & $<0.1$ & 22 & 4.9 & 0.105 & 33 & $<0.1$ & $<0.1$ & $<0.1$ & $\mathrm{H} / \mathrm{O}$ & 9.8 & 0.016 \\
\hline 1 & 0.5 & 0.3 & 0.2 & 1.5 & 3.6 & 0.093 & 34 & 0.4 & 0.1 & 0.3 & 0.3 & 11.8 & 0.012 \\
\hline 10 & 1.3 & 0.7 & 0.6 & 1.2 & 5.8 & 0.070 & 35 & 1.3 & 0.3 & 1.0 & 0.35 & 7.7 & 0.014 \\
\hline 11 & 0.9 & 0.5 & 0.4 & 1.3 & 4.1 & 0.061 & 36 & $<0.1$ & $<0.1$ & $<0.1$ & $\mathrm{H} / \mathrm{O}$ & 7.8 & 0.044 \\
\hline 12 & $<0.1$ & $<0.1$ & $<0.1$ & $\mathrm{H} / \mathrm{O}$ & 2.9 & 0.048 & $36 \mathrm{a}$ & 0.6 & 0.2 & 0.4 & 0.5 & $\mathrm{H} / \mathrm{O}$ & 0.040 \\
\hline 13 & 0.6 & 0.3 & 0.3 & 1.0 & 7.7 & 0.091 & \multicolumn{4}{|c|}{ Среднее значение } & 0.8 & 6.4 & 0.063 \\
\hline 14 & 0.4 & 0.3 & 0.1 & 3 & 5.8 & 0.115 & \multicolumn{7}{|c|}{ Месторождение Талатуй } \\
\hline 15 & 0.4 & 0.4 & $<0.1$ & $>4$ & 7.9 & 0.133 & 37 & 0.5 & $<0.1$ & 0.5 & $<0.2$ & 5.4 & $<0.010$ \\
\hline 16 & 1.0 & 0.7 & 0.3 & 2.3 & 4.2 & 0.131 & 38 & 1.7 & 0.2 & 1.5 & 0.1 & 6.0 & $\sim 0.020$ \\
\hline 17 & 0.5 & 0.3 & 0.2 & 1.5 & 6.6 & 0.082 & 39 & 3.1 & $<0.1$ & 3.1 & $<0.03$ & 18.5 & $<0.020$ \\
\hline 18 & 0.7 & 0.3 & 0.4 & 0.8 & 6.6 & 0.070 & 40 & 0.5 & $<0.1$ & 0.5 & $<0.2$ & 6.3 & 0.010 \\
\hline 21 & 0.3 & 0.2 & 0.1 & 2 & 4.6 & 0.032 & 41 & 9.5 & 0.7 & 8.8 & 0.08 & 9.4 & $<0.020$ \\
\hline $\mathrm{Cp}$ & неe $3 \mathrm{H}$ & гение & & $>2.2$ & 4.8 & 0.096 & 42 & 0.3 & 0.1 & 0.2 & 0.5 & 4.9 & $<0.020$ \\
\hline \multicolumn{7}{|c|}{ Месторождение Дарасун (брекчия) } & 43 & 6.0 & 0.3 & 5.7 & 0.05 & 18.3 & $<0.005$ \\
\hline 19 & 3.9 & 1.2 & 2.7 & 0.4 & 7.7 & $\sim 0.020$ & 44 & 3.4 & 0.3 & 3.1 & 0.1 & 15.1 & $<0.007$ \\
\hline 20 & 4.8 & 2.0 & 2.8 & 0.7 & 8.7 & $\sim 0.020$ & 45 & 1.6 & $<0.1$ & 1.6 & $<0.06$ & 12.7 & $<0.020$ \\
\hline $\mathrm{Cp}$ & нее $3 \mathrm{H}$ & гение & & 0.55 & 8.2 & $\sim 0.020$ & & $\begin{array}{r}10.7 \\
5.5\end{array}$ & $\begin{array}{l}0.8 \\
0.3\end{array}$ & $\begin{array}{l}9.9 \\
5.2\end{array}$ & $\begin{array}{l}0.08 \\
0.06\end{array}$ & $\begin{array}{l}19.8 \\
16.8\end{array}$ & $\begin{array}{l}<0.020 \\
<0.020\end{array}$ \\
\hline \multicolumn{7}{|c|}{ Месторождение Теремкинское } & 46 & 6.2 & 0.6 & 5.6 & 0.1 & 15.7 & $<0.020$ \\
\hline 22 & 0.3 & 0.1 & 0.2 & 0.5 & 7.0 & 0.244 & 47 & 1.6 & 0.3 & 1.3 & 0.2 & 16.8 & 0.018 \\
\hline 23 & 0.3 & 0.2 & 0.1 & 2 & 2.1 & 0.143 & 48 & 3.2 & 0.2 & 3.0 & 0.07 & 7.0 & 0.012 \\
\hline $23 a$ & 0.3 & 0.2 & 0.1 & 2 & 2.1 & 0.115 & \multicolumn{4}{|c|}{ Среднее значение } & $<0.13$ & 12.3 & $<0.020$ \\
\hline
\end{tabular}

$C_{\mathrm{Ti}(\mathrm{H})} / C_{\mathrm{Ti}(\mathrm{Li})}$ от $N_{\mathrm{Ti}}$ для каждого из месторождений Дарасунского рудного поля приведены на фиг. 4.

Подвижность ионов-компенсаторов в кварuе. Рассматривались факторы, влияющие на скорость диффузии ионов-компенсаторов в структурных каналах кварца. Главными из них считались природа самих ионов и дефектность кристаллического строения кварца.

Об индивидуальных диффузионных свойствах ионов $\mathrm{H}^{+}, \mathrm{Li}^{+}$и $\mathrm{Na}^{+}$судили по скорости нако-

пления $\mathrm{Ti}(\mathrm{H})-$, $\mathrm{Ti}(\mathrm{Li})-$ и $\mathrm{Ti}(\mathrm{Na})$-центров при радиационном облучении кварца. Для удобства использовались нормированные концентрации этих центров, равные отношению $C_{\mathrm{Ti}} / C_{\mathrm{Ti}}$ max, где $C_{\mathrm{Ti}}-$ текущие концентрации центров, a $C_{\mathrm{Ti}}{ }_{\max }$ - максимальная из них.

На фиг. 5 приведены графики дозовых зависимостей для каждого типа Ті-центров. Видно, что они имеют куполообразный вид и отличаются местоположением относительно оси абсцисс. Собственно говоря, куполообразная форма дозовых 


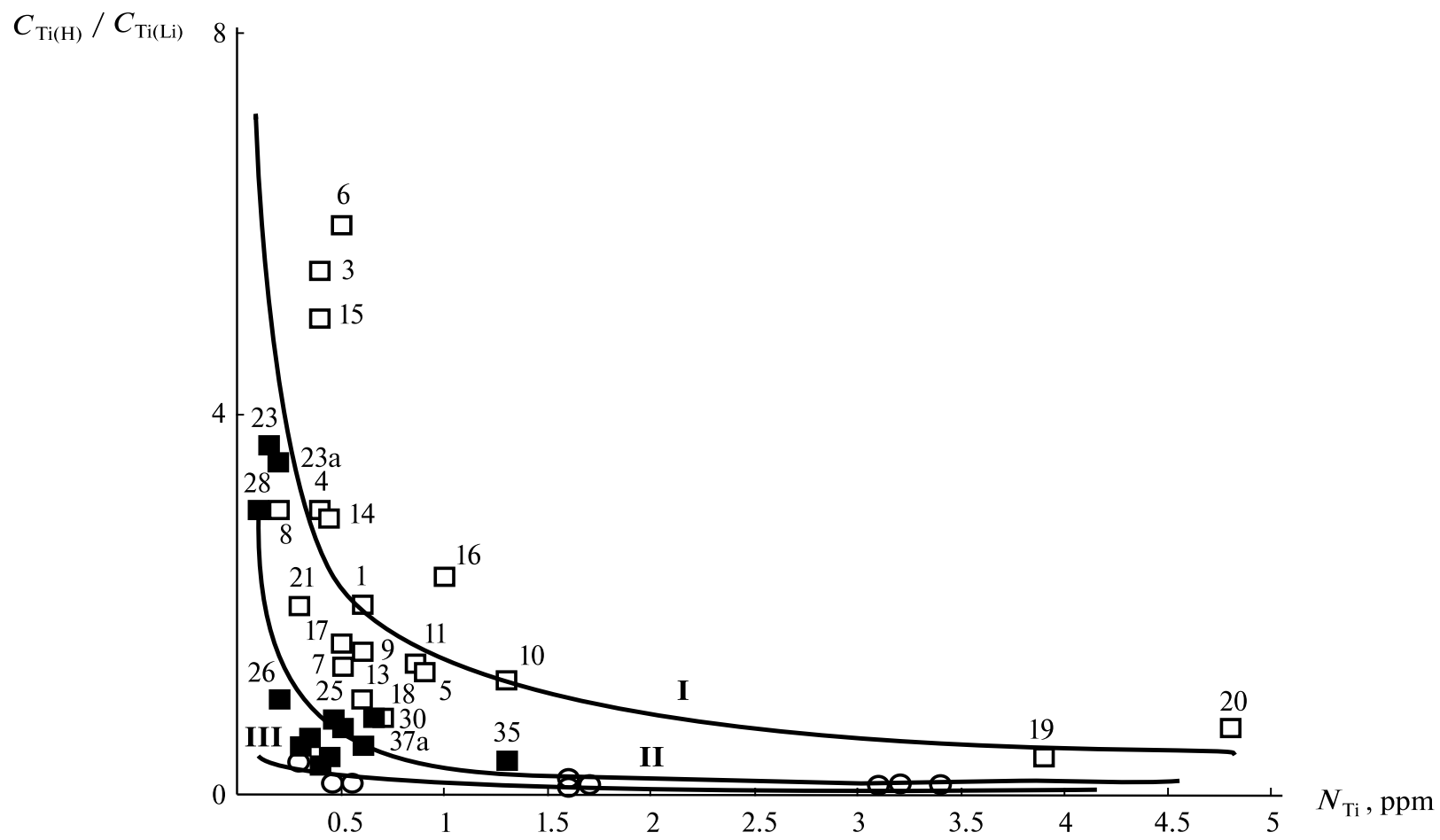

Фиг. 4. Зависимость соотношения концентраций ионов $\mathrm{H}^{+}$и $\mathrm{Li}^{+}$в структурных каналах $\left(C_{\mathrm{Ti}(\mathrm{H})} / C_{\mathrm{Ti}(\mathrm{Li})}\right)$ от содержания в кварце изоморфного Ті $\left(N_{\mathrm{Ti}}\right)$ для месторождений Дарасун (I), Теремкинское (II) и Талатуй (III). Здесь и на последующих графиках цифры, которыми обозначены экспериментальные точки, - лабораторные номера образцов (табл. 1 и 2). Точки на графике: $\square-$ месторождение Дарасун; $\mathbf{\square}-$ месторождение Теремкинское; О - месторождение Талатуй.

кривых $C_{\mathrm{Ti}} / C_{\mathrm{Ti}}{ }^{\max }$ от $D$ является характерной для Ті-центров. Она отражает течение двух разнонаправленных процессов - образования центров при малых дозах облучения и их распада - при больших (Раков, Моисеев, 1992). Положение кривых относительно оси абсцисс определяется скоростью накопления Ті-центров и может быть

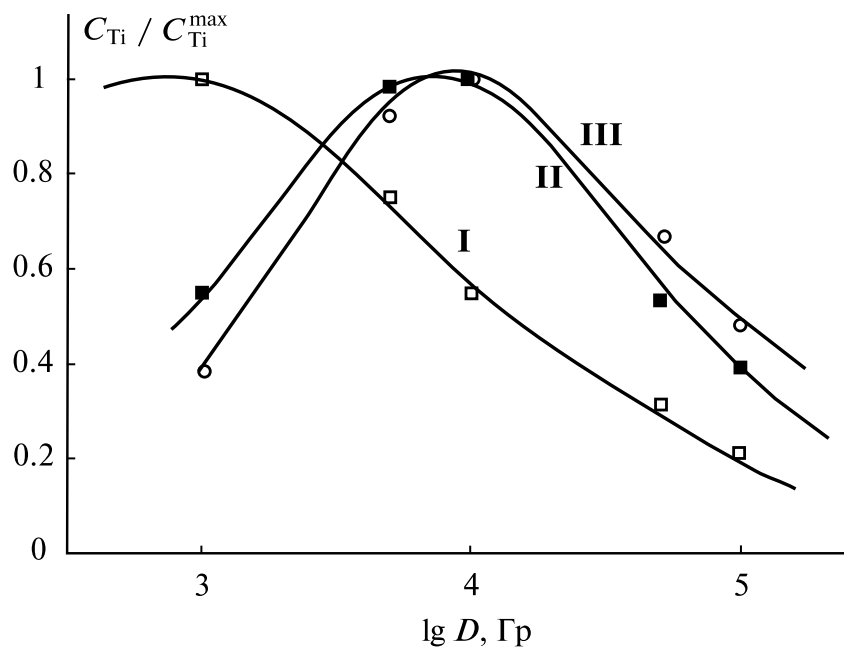

Фиг. 5. Типичный вид зависимости нормированных концентраций $\mathrm{Ti}(\mathrm{H})-(\mathrm{I}), \mathrm{Ti}(\mathrm{Li})$ - (II) и $\mathrm{Ti}(\mathrm{Na})$ центров (III) в образцах прогретого кварца брекчий месторождения Дарасун от дозы радиационного облучения $D$. использовано для оценки скорости миграции ионов-компенсаторов. Как упоминалось ранее, скорость накопления $\mathrm{Ti}(\mathrm{H})-$, $\mathrm{Ti}(\mathrm{Li})-$ или $\mathrm{Ti}(\mathrm{Na})$ центров определяется скоростью диффузии ионов-компенсаторов $\mathrm{H}^{+}, \mathrm{Li}^{+}$или $\mathrm{Na}^{+}$соответственно. Чем она выше, тем меньшая доза облучения требуется для накопления полной концентрации Ті-центров соответствующего вида.

Анализ взаимного расположения дозовых кривых $C_{\mathrm{Ti}} / C_{\mathrm{Ti}}^{\text {max }}$ от $D$ на фиг. 5 показывает, что наибольшую скорость диффузии имеют протоны. Кривая для $\mathrm{Ti}(\mathrm{H})$-центров занимает крайнее левое положение по оси абсцисс, демонстрируя, что при радиационном облучении кварца они образуются в первую очередь. Смешение максимумов кривых $C_{\mathrm{Ti}} / C_{\mathrm{Ti}}{ }^{\text {max }}$ от $D$ для $\mathrm{Ti}(\mathrm{Li})$ - и $\mathrm{Ti}(\mathrm{Na})$-центров в сторону более высоких доз свидетельствует о существенно меньшей скорости миграции ионов $\mathrm{Li}^{+}$и $\mathrm{Na}^{+}$в структурных каналах кварца.

Обнаружено, что при переходе от кварца группы “U” к кварцу группы “A" наблюдается стремительное уменьшение концентрации $\mathrm{Ti}(\mathrm{Na})$-центров и еще большее смещение в сторону высоких доз максимума дозовой кривой для $\mathrm{Ti}(\mathrm{Li})$-центров. При этом положение кривой $C_{\mathrm{Ti}} / C_{\mathrm{Ti}}{ }^{\max }(D)$ для $\mathrm{Ti}(\mathrm{H})$-центров, наоборот, смещается в сторону меньших доз. В результате разброс в значениях доз, отвечающих максимумам 
дозовых кривых $\mathrm{Ti}(\mathrm{H})-$ и $\mathrm{Ti}(\mathrm{Li})$-центров, может достигать двух порядков.

Влияние дефектности кристаллического строения кварца на скорость миграции ионов-компенсаторов оценивалось по характеру зависимости скорости образования $\mathrm{Al}^{-} \mathrm{O}^{-}$-центров $\theta$ от величины отношения $C_{\mathrm{Al}-\mathrm{X}} / C_{\mathrm{Al}}$. На фиг. 6 представлен график этой зависимости для образцов кварца исследуемой коллекции. Его рассмотрение показывает, что с увеличением отношения $C_{\mathrm{Al}-\mathrm{X}} / C_{\mathrm{Al}}$ величина $\theta$ уменьшается. Обращает на себя внимание большой разброс точек на графике, особенно в его средней части. Тем не менее, для всех образцов кварца Дарасунского рудного поля и семи дополнительных образцов наблюдается единая закономерность.

Динамика образования $\mathrm{Al}-\mathrm{O}^{-}$-центров в исследуемом кварие. Ход накопления парамагнитных центров при радиационном облучении является важной характеристикой кварца, позволяющей установить его принадлежность к группам "U” или “А”. Наиболее достоверно она определяется по виду зависимостей $C_{\mathrm{Al}}(D)$ при дозах облучения $D \sim 10^{2}$ Гр (Раков, 1999). Однако из-за низкого содержания изоморфного $\mathrm{Al}$ в исследуемых образцах кварца концентрации $\mathrm{Al}-\mathrm{O}^{-}$-центров, возникающие при таких дозах, слишком малы для их уверенной регистрации. Поэтому в качестве критерия принадлежности кварца к какой-либо из групп была выбрана форма графика зависимости $\theta$ от величины $N_{\mathrm{Al}}$. Ранее было показано, что она отражает динамику образования парамагнитных центров в кварце (Раков, 2003).

Фиг. 7 иллюстрирует графики зависимости $\theta\left(N_{\mathrm{Al}}\right)$ для кварца из месторождений Талатуй, Теремкинское и Дарасун. По своему виду они различны. Для месторождения Талатуй график представляет собой прямую линию с отрицательным углом наклона (фиг. 7а). Графики для месторождений Теремкинское и Дарасун характеризуются большим разбросом точек и не могут быть с достаточной достоверностью выражены какими-либо кривыми. Правомерно говорить лишь о тренде их поведения. При линейной аппроксимации данным графикам соответствуют прямые линии с положительными углами наклона (фиг. 7б и 7в).

Дефектность кристаллической структуры квариа. Исследование зерен кварца месторождений Дарасунского рудного поля под оптическим микроскопом показало, что им свойственны волнистое угасание и блочность, свидетельствующие о деформации кристаллической структуры минерала. Обработка пластин кварца в плавиковой кислоте и изучение их методом РЭМ позволили выявить дополнительные детали его кристаллического строения.

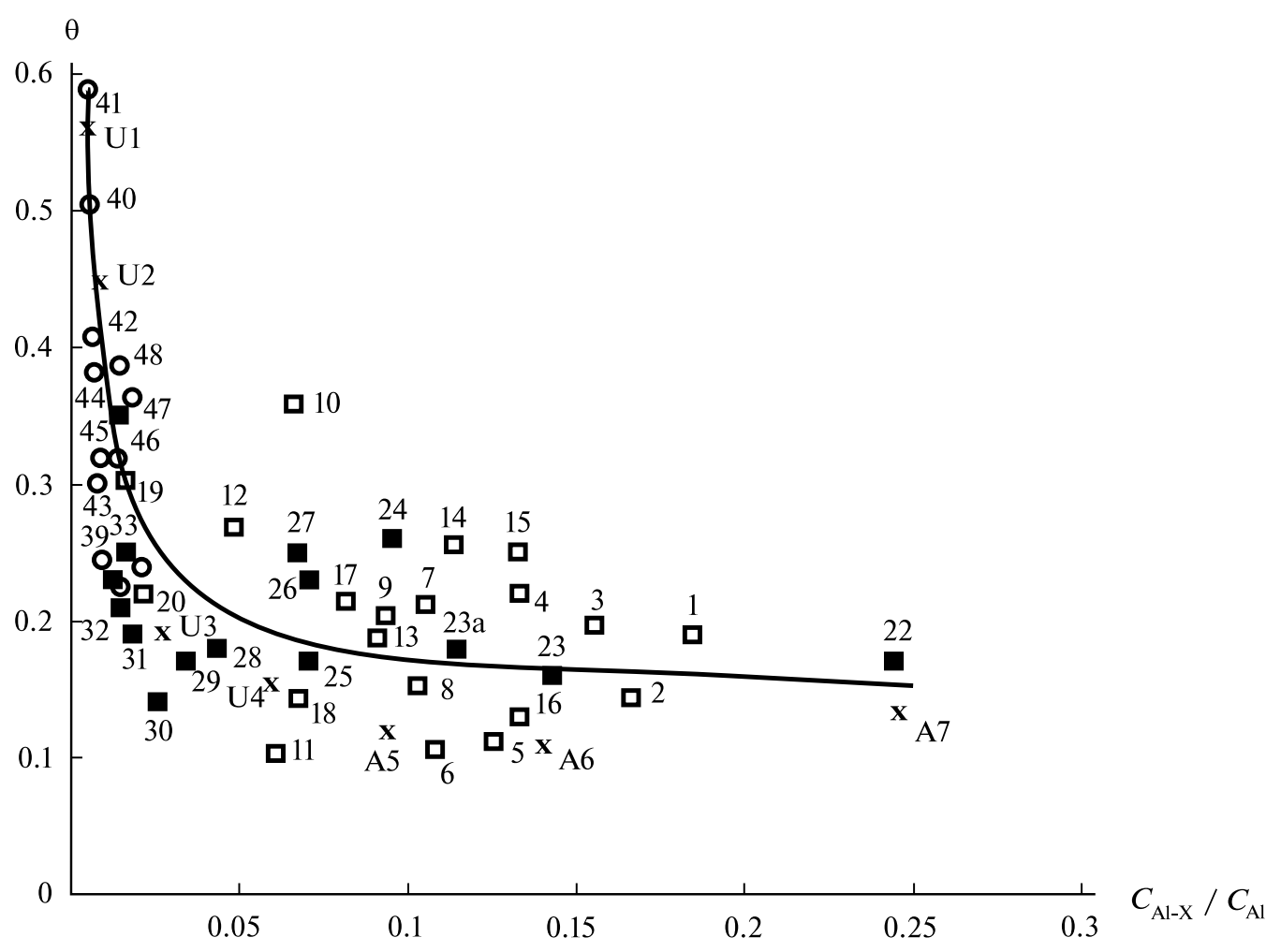

Фиг. 6. Зависимость скорости образования $\mathrm{Al- \textrm {O } ^ { - } - ц е н т р о в ~} \theta$ в кварце Дарасунского рудного поля от величины $C_{\mathrm{Al}-\mathrm{X}} / C_{\mathrm{Al}}$. Точки на графике: $\square-$ месторождение Дарасун; $\mathbf{\square}-$ месторождение Теремкинское; О - месторождение Талатуй; $x$ - образцы с известной принадлежностью к группам “Урал” и “Алдан”. 


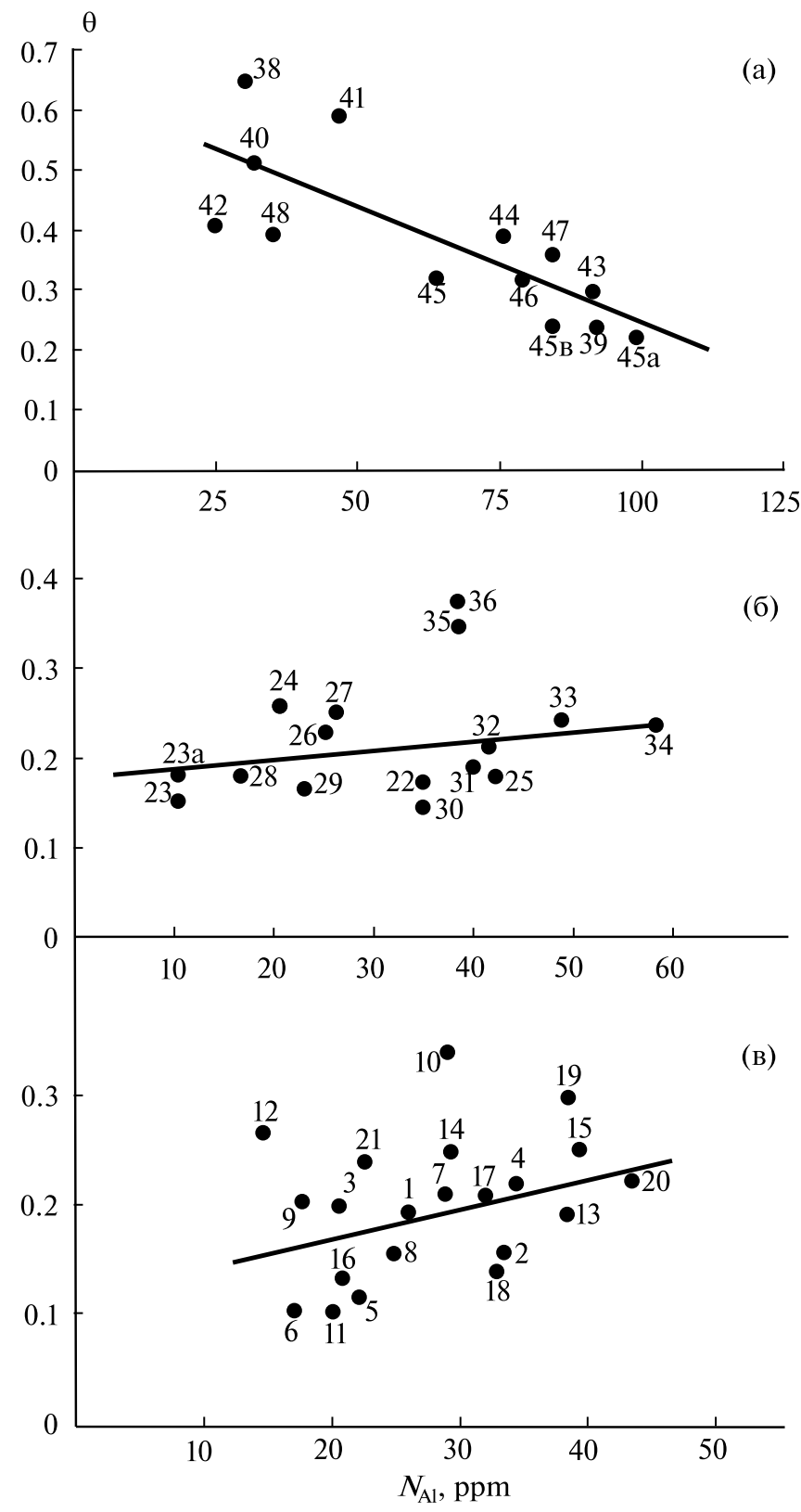

Фиг. 7. Графики зависимости радиационной чувствительности $\theta$ кварца месторождений Талатуй (a), Теремкинское (б) и Дарасун (в) от содержания изоморфного алюминия $N_{\mathrm{Al}}$.

Установлено большое разнообразие размеров и форм кристаллитов в исследуемых образцах (фиг. 8). Для месторождений Теремкинское и Дарасун кристаллиты порой имеют форму кристаллов кварца размером до 100 мкм (фиг. 8а). Воздействие плавиковой кислоты приводит к их избирательному травлению, главным образом, вдоль направления оси третьего порядка. Очень часто кристаллиты встречаются в виде кварцевых зерен размером в десятки мкм и более мелких зерен, располагающихся по их границам (фиг. 8б). Весьма типичным для этих месторож- дений является наличие кристаллитов различных форм и размеров, хаотично разбросанных относительно друг друга (фиг. 8в). В некоторых из них обнаруживается сотовая структура, вскрываемая травлением в HF (фиг. 8г).

В кварце из месторождения Талатуй увеличивается средний размер кристаллитов, который иногда достигает нескольких мм (фиг. 8д). При большом увеличении в кристаллитах повсеместно наблюдается сотовая структура (фиг. 8е).

\section{ОБСУЖДЕНИЕ РЕЗУЛЬТАТОВ}

Результаты исследований позволяют расширить наши представления о природе появления подвижных примесей в кристаллической матрице минерала, особенностях их диффузии в структурных каналах и дают возможность использовать обнаруженные закономерности для изучения геологических процессов, протекавших на Дарасунском рудном поле.

Захват примесей кварием в процессе кристаллизации. Сопоставление данных исследования флюидных включений (табл. 3) с результатами изучения кварца методом ЭПР (табл. 4) свидетельствует об отсутствии зависимости концентрации Li в структурных каналах кварца от его содержания в минералообразующем флюиде. Действительно, наименьшая доля $\mathrm{Li}^{+}$в составе ионов-компенсаторов Ті-центров регистрируется в кварце месторождения Дарасун, а наибольшая - в кварце месторождения Талатуй. Однако минералообразующий флюид месторождения Дарасун содержит заметно больше лития, чем флюид месторождения Талатуй. Следовательно, внедрение ионов подвижных примесей в матрицу минерала при кристаллизации подчиняется особым закономерностям.

Можно предположить, что основным фактором, определяющим интенсивность этого процесса, является температура. Ее особая роль обусловлена двумя причинами.

Во-первых, с повышением температуры экспоненциально растет диффузионная подвижность ионов примесей, благоприятствующая их проникновению в кристаллическую структуру кварца.

Во-вторых, при высоких температурах начинают протекать полиморфные превращения в природном кремнеземе, приводящие к появлению “рыхлых" кристаллических структур (Бетехтин, 1950). Уже при $T \approx 573{ }^{\circ} \mathrm{C}$ возникает высокотемпературная модификация кварца, имеющая меньшую плотность и более доступная для внедрения в нее ионов примесей. Интересно, что для месторождений Дарасун и Теремкинское максимальные температуры образования кварца ниже этого значения, а для месторождения Талатуй - выше (табл. 3). 
Следует отметить, что отсутствует корреляция и между содержанием Ті и Ge во флюидных включениях (табл. 3) и концентрацией изоморфных примесей Ті (табл. 4) и Ge в минерале (Раков и др., 2019).

Условия протекания диффузии в структурных каналах квариа. Полученные данные свидетельствуют о специфических условиях, в которых осуществляется диффузия ионов-компенсаторов в структурных каналах кварца.

Главное из них - ограниченные размеры поперечного сечения структурных каналов. Известно, что их диаметр не превышает 0.26 нм (Бетехтин, 1950). Это обстоятельство существенно сужает круг одновалентных ионов, способных диффундировать в структурных каналах кварца. Проникать в них могут только ионы $\mathrm{Li}^{+}$и $\mathrm{Na}^{+}$, диаметры которых, согласно оценкам Н.В. Белова и Б.М.Бокия, соответственно равны 0.136 и 0.196 нм (Справочник химика, 1982). Даже ион $\mathrm{K}^{+}$, имеющий диаметр 0.266 нм, не в состоянии мигрировать в структурных каналах минерала.

Видимо, поэтому в исследованном нами кварце наиболее часто в структурных каналах встречались ионы $\mathrm{Li}^{+}$, и лишь в отдельных образцах ионы $\mathrm{Na}^{+}$. Причем появление $\mathrm{Na}^{+}$отмечалось после прогрева кварца при $T=900{ }^{\circ} \mathrm{C}$, стимулирующего диффузионные процессы в структурных каналах. Высокая диффузионная подвижность ионов $\mathrm{Li}^{+}$по сравнению с $\mathrm{Na}^{+}$объясняется их меньшими размерами. Поэтому в кварце с содержанием лития, достаточным для нейтрализации электрического заряда всех точечных дефектов, ионы $\mathrm{Na}^{+}$всегда вытесняются из структурных каналов ионами $\mathrm{Li}^{+}$(Раков, Шурига, 2009).

Исключительная роль в процессах диффузии в кварце принадлежит ионам $\mathrm{H}^{+}$. Известно, что диаметр протонов в $10^{5}$ раз меньше диаметра щелочных ионов (Niederberger, 2010). Отсюда представляется вполне закономерным вид графиков дозовых зависимостей для $\mathrm{Ti}(\mathrm{H})-, \mathrm{Ti}(\mathrm{Li})-$ и $\mathrm{Ti}(\mathrm{Na})$-центров, изображенных на фиг. 5. Из их рассмотрения следует, что скорость диффузии протонов в структурных каналах на 1-2 порядка превышает скорость ионов $\mathrm{Li}^{+}$и $\mathrm{Na}^{+}$.

Другим фактором, влияющим на диффузию ионов-компенсаторов в структурных каналах кварца, является степень совершенства его кристаллической структуры. Разнообразные нарушения кристаллической решетки способны не только снизить проходимость структурных каналов, но и полностью перекрыть их для диффузии щелочных ионов. График на фиг. 6 демонстрирует поведение скорости образования $\mathrm{Al}-\mathrm{O}^{-}$-центров $\theta$ в кварце при повышении уровня его дефектности. Обращает на себя внимание быстрый, почти гиперболический спад левого крыла графика. Однако в его правой части, отвечающей
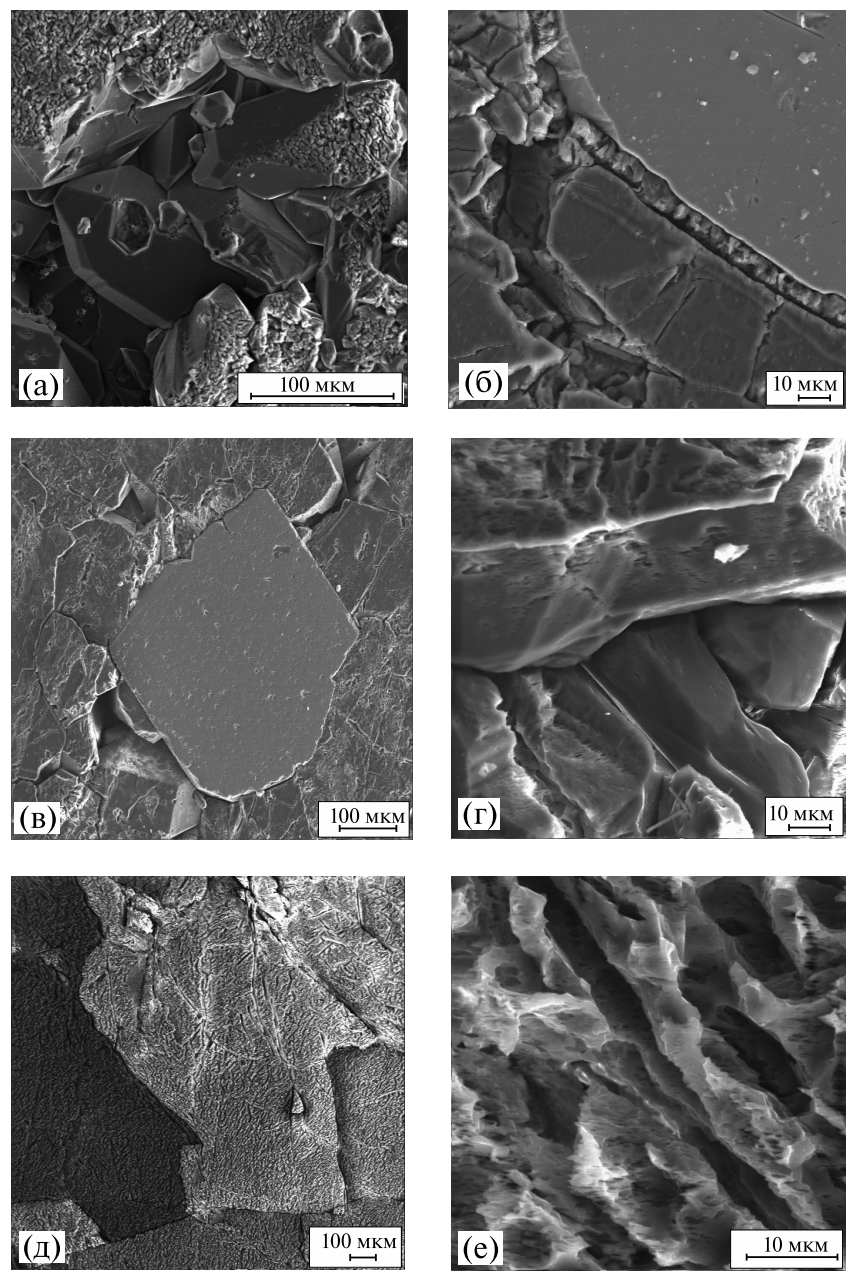

Фиг. 8. Микрофотографии кристаллитов в образцах кварца Дарасунского рудного поля: (а) - обр. 23a (месторождение Теремкинское); (б) - обр. 34 (месторождение Теремкинское); (в) и (г) - обр. 21 (месторождение Дарасун); (д) и (е) - обр. 46 (месторождение Талатуй)

наиболее дефектным образцам, величина $\theta$ не уменьшается до нуля, а принимает постоянное значение. Для них же отмечаются и наивысшие значения отношения $C_{\mathrm{Ti}(\mathrm{H})} / C_{\mathrm{Ti}(\mathrm{Li})}$ (фиг. 4$)$.

Обнаруженные закономерности свидетельствуют о том, что диффузия ионов-компенсаторов в структурных каналах кварца не прекращается даже при высокой дефектности кварца. Причем основными ионами-компенсаторами, обеспечивающими электрическую нейтральность центров, становятся протоны. Это означает, что с повышением степени дефектности кварца их преимущество в подвижности перед другими ионами-компенсаторами возрастает. Причиной тому могут служить особенности процесса диффузии ионов $\mathrm{H}^{+}$, обусловленные отсутствием у них электронов.

Известно, что самым распространенным механизмом этой диффузии является перенос протонов по цепочкам молекул воды, соединен- 
ных водородными связями (механизм Гротгуса) (De Grotthuss, 1806). Нельзя исключить, что подобные цепочки могут формироваться в зонах дефектности кварца. В них, как было установлено, концентрируются кристаллиты кварца, вытянутые в одном направлении и параллельные друг другу (Раков и др., 2015). Похожая ориентация может возникать и у молекул воды, локализованных на поверхности кристаллитов, что делает осуществимым механизм Гротгуса.

Однако более вероятным в данном случае представляется перенос протонов по механизму прыжковой диффузии по структурным дефектам, имеющим эффективный отрицательный заряд (Урицкий, Цидильковский, 2014). Такого рода дефекты в значительных количествах возникают при радиационном облучении кварца. Чаще всего они связаны с кислородными вакансиями, изоморфными атомами Тi и $\mathrm{Ge}$, другими типами структурных дефектов, захвативших электроны. Перескакивая с одного дефекта на другой и имея малые размеры, протоны могут приобретать бо́льшую подвижность, чем обычные ионы-компенсаторы. Сама возможность захвата дефектами ионов протонов подтверждается наличием в кварце целой группы парамагнитных центров с ионами-компенсаторами $\mathrm{H}^{+}$ (Weil, 1984), а также радикалов с двумя эквивалентными и одним неэквивалентным протоном, которые были обнаружены авторами в дефектном кварце. Оба рассмотренных механизма, по литературным источникам, обеспечивают более высокую скорость диффузии протонов по сравнению с другими ионами.

Скорость миграции ионов $\mathrm{Li}^{+}$, согласно полученным данным, наоборот, уменьшается с повышением дефектности кварца. Эта тенденция, видимо, обусловлена ближним порядком и, как следствие, деформацией структурных каналов. Кроме того, дефектные зоны обогащены атомами примесей, часть которых способна проникать в структурные каналы. Некоторые из них, например ионы $\mathrm{Fe}^{3+}$, могут занимать междоузельное положение и препятствовать диффузии щелочных ионов (Lehmann, 1971). Непроходимость структурных каналов также может быть создана дислокациями, микродвойниками и другими протяженными дефектами в кварце. В связи с этим замедляется диффузия щелочных ионов и затормаживаются процессы формирования и распада $\mathrm{Al}^{-\mathrm{O}^{-}-}$и Ті-центров (Раков, 1992). Вместе с тем, перечисленные структурные нарушения не в состоянии изменить скорость переноса протонов, имеющих ничтожные относительно щелочных ионов размеры.

Особенности диффузии ионов-компенсаторов объясняют различия в содержаниях Li в структурных каналах и во флюидных включениях.
Последние концентрируются в зонах дефектности, где скорость диффузии ионов $\mathrm{Li}^{+}$мала, что тормозит обмен литием между флюидными включениями и структурными каналами.

В областях относительно упорядоченной кристаллической структуры резко падает концентрация кислородных вакансий и других дефектов в кварце. В результате скорость диффузии протонов уменьшается, и основными ионами-компенсаторами становятся $\mathrm{Li}^{+}$.

Проиессы динамической рекристаллизации квариа Дарасунского рудного поля. Данные методов оптической и электронной микроскопии свидетельствуют, что кварц Дарасунского рудного поля подвергался динамической рекристаллизации. Интенсивность этого процесса в разных образцах неодинакова. Более того, не остается она постоянной и в границах одного образца, о чем говорит различный вид кристаллитов. Тем не менее, при переходе от одного месторождения к другому наблюдается общая закономерность изменения характера рекристаллизации.

Наименьшую динамическую рекристаллизацию испытал кварц месторождения Дарасун. В нем замечены такие признаки ее реализации, как наличие волнистого угасания и присутствие мелких зерен на границах крупных микроблоков кварца (фиг. 8б). При этом велика концентрация неизмененных кристаллитов (фиг. 8а). Подобная картина типична для начальной стадии динамической рекристаллизации кварца, обусловленной механизмом вспучивания границ зерен (BLG bulging) (Hirth, Tullis, 1992).

В образцах из месторождения Теремкинское сокращается количество зерен кварца, не затронутых процессом динамической рекристаллизации. Появляются новые кристаллиты, возникающие не на границах микроблоков или в трещинах, а за счет разрушения первичных зерен кварца и смещения новообразованных частей относительно друг друга (фиг. 8в). Эти признаки характерны для механизма динамической рекристаллизации, связанного с субзерновым вращением (SGR - subgrain rotation) (Urai et al., 1986).

Кварцу из месторождения Талатуй свойственна полная рекристаллизация, зерна первичного вида отсутствуют. Размеры кристаллитов в нем намного больше, чем в образцах кварца из месторождений Дарасун и Теремкинское (фиг. 8д). Границы их изрезаны, наблюдается взаимное проникновение кристаллитов друг в друга. Динамическая рекристаллизация, приводящая к появлению кристаллитов описанного вида, вызвана высокотемпературной миграцией границ зерен (GBM - grain boundary migration) (Urai et al., 1986).

Проведенная обработка кварца в HF позволила обнаружить дополнительный признак ди- 
намической рекристаллизации по механизму GBM - появление сотовой структуры минерала (фиг. 8е). Его использование дает возможность повысить надежность идентификации и снизить порог обнаружения GBM-рекристаллизации кварца. В качестве примера, иллюстрирующего эффективность нового признака, можно привести микрофотографию на фиг. 8г. На ней видно, как обработка в плавиковой кислоте помогает выявить даже слабое проявление динамической рекристаллизации по механизму GBM. Без обработки в НF зерна на фиг. 8г можно было бы ошибочно отнести к первичным кристаллитам.

Известно, что каждый из механизмов динамической рекристаллизации кварца протекает в условиях деформации минерала в определенном интервале температур (Urai et al., 1986; Passchier, Trouw, 1996). Механизм BLG реализуется при температурах $250-400{ }^{\circ} \mathrm{C}, \mathrm{SGR}$ - при $400-500{ }^{\circ} \mathrm{C}$, а механизм GBM доминирует при $500-550{ }^{\circ} \mathrm{C}$ и выше.

Результаты исследования процесса динамической рекристаллизации кварца Дарасунского рудного поля показывают, что наиболее высокотемпературные условия наблюдаются на месторождении Талатуй. Существенно меньшими температурами характеризуется месторождение Теремкинское, и еще более низкими - месторождение Дарасун. Диапазоны температур, соответствующие процессам динамической рекристаллизации кварца, совпадают с оценками, полученными при изучении флюидных включений (табл. 3).

Оиенка степени динамической рекристаллизаиии методом ЭПР. Взаимосвязь динамической рекристаллизации с дефектностью кристаллической структуры кварца создает условия для обнаружения ее методом ЭПР.

Результаты исследований подтвердили правомерность использования в этих целях параметра $C_{\mathrm{Al}-\mathrm{X}} / C_{\mathrm{Al}}$. Его величина, пропорциональная соотношению объемов неупорядоченной и совершенной кристаллических структур, позволяет проследить изменение дефектности кварца в процессе развития динамической рекристаллизации минерала и оценить ее количественно. В самом деле, интенсивность рекристаллизации кварца возрастает при переходе от месторождения Дарасун к месторождению Теремкинское и далее к Талатуй. В той же последовательности изменяется и параметр $C_{\mathrm{Al}-\mathrm{X}} / C_{\mathrm{Al}}$. Если для месторождения Дарасун его среднее значение равно 0.096, то для Теремкинского месторождения оно уменьшается до 0.063 , а для месторождения Талатуй падает ниже 0.020 (табл. 4).

Заметим, что неопределенность строения Al-X-центров может вносить погрешности в результаты оценки динамической рекристаллизации кварца с использованием параметра $C_{\mathrm{Al}-\mathrm{X}} / C_{\mathrm{Al}}$. Не исключено, что Al-Х-центры содержат ионыкомпенсаторы $\mathrm{H}^{+}$, число которых велико в зонах дефектности. В этом случае значение $C_{\mathrm{Al}-\mathrm{X}} / C_{\mathrm{Al}}$ будет зависеть не только от дефектности кварца, но и от концентрации протонов.

Оценка степени динамической рекристаллизации методом ЭПР может проводиться и по содержанию в кварце изоморфного титана. Действительно, упорядочение кристаллической структуры минерала приводит к росту в нем концентраций изоморфных примесей (Раков, 2006; Раков и др., 2019). Наиболее отчетливо это проявляется на высокотемпературной стадии, протекающей по механизму GBM. Приведенные в табл. 4 значения $N_{\mathrm{Ti}}$ и $N_{\mathrm{Al}}$ показывают, что в кварце месторождения Талатуй, где доминирует указанная стадия рекристаллизации, наблюдается резкий рост средних содержаний изоморфного Ті и Al. Из них структурный титан имеет особое индикаторное значение.

Дело в том, что, как указывалось выше, изоморфный Ті возникает только при динамической рекристаллизации кварца (Раков и др., 2019). K тому же с увеличением температуры образования кварца, а значит и температуры его динамической рекристаллизации, наблюдается рост значения $N_{\mathrm{Ti}}$ (Бершов и др., 1975). Эти особенности примеси изоморфного Ті позволяют использовать величину $N_{\text {Ті }}$ для оценки интенсивности динамической рекристаллизации кварца.

Следует отметить, что при повышении степени динамической рекристаллизации отношение $C_{\mathrm{Al}-\mathrm{X}} / C_{\mathrm{Al}}$ уменьшается, а значение $N_{\mathrm{Ti}}$ растет. Такое поведение параметров благоприятно для их совместного использования. Соотношение $C_{\mathrm{Al}-\mathrm{X}} / C_{\mathrm{Al}}$ целесообразно применять для оценки слабой динамической рекристаллизации кварца, когда величина $N_{\mathrm{Ti}}$ близка к нулю. Содержание изоморфного Тi, наоборот, информативно в случаях интенсивного проявления рекристаллизации, когда значение $C_{\mathrm{Al}-\mathrm{X}} / C_{\mathrm{Al}}$ может не превышать порога обнаружения. В настоящей работе используется оба эти параметра (фиг. 4 и 6).

Необходимо подчеркнуть, что ни один структурный параметр не в состоянии отразить все многообразие дефектной среды, а само понятие “дефектность" носит относительный характер. Поэтому значения параметров $C_{\mathrm{Al}-\mathrm{X}} / C_{\mathrm{Al}}$ и $N_{\mathrm{Ti}}$ могут использоваться только для полуколичественной оценки динамической рекристаллизации кварца. В то же время эта оценка достаточно объективна и имеет определенные преимущества перед локальными методами изучения динамической рекристаллизации минерала.

Принадлежсность квариа Дарасунского рудного поля $\kappa$ группам “ $U$ ” $u$ “ $A$ ”. Анализ графиков зависимости $\theta\left(N_{\mathrm{Al}}\right)$, приведенных на фиг. 7 , 
дает возможность определить принадлежность образцов кварца Дарасунского рудного поля к группам "U" или "A".

Вид графика зависимости $\theta\left(N_{\mathrm{Al}}\right)$ для месторождения Талатуй (фиг. 7а) типичен для кварца группы “U”. Как было показано в работе (Раков, 2003), скорость образования $\mathrm{Al}^{-\mathrm{O}^{-}-ц е н т р о в ~ в ~}$ кварце этой группы пропорциональна величине удельной ионизации, которая при малых дозах облучения линейно уменьшается с ростом $N_{\mathrm{Al}}$. Подобная закономерность появляется, когда процесс образования $\mathrm{Al}^{-} \mathrm{O}^{-}$-центров перестает зависеть от диффузии ионов-компенсаторов и описывается механизмом свободного заполнения ловушек дырками (Раков, 1997).

Для образцов из руд месторождения Теремкинское и, особенно, из руд месторождения Дарасун зависимости $\theta\left(N_{\mathrm{Al}}\right)$ отклоняются от закономерности, представленной на фиг. 7а. Это означает, что для них не выполняются условия свободного заполнения ловушек дырками, и на

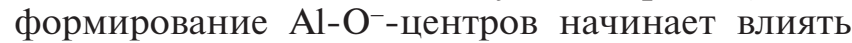
диффузия ионов-компенсаторов. Поэтому образцы из руд указанных месторождений в своей массе не могут быть отнесены к группе "U”. Можно допустить, что значительная их часть относится к группе “А” или занимает промежуточное между "U" и "A" положение.

Природа различий между образиами кварu, груnn “ $U$ ” $u$ “ $A$ ”. Как и предполагалось, наблюдаемые различия в скорости накопления парамагнитных центров в кварце групп "U” и "A" вызваны разной диффузионной подвижностью щелочных ионов, прежде всего $\mathrm{Li}^{+}$. По всей видимости, в кварце группы “U” их переход к другим дефектам осуществляется легко и никак не ограничивает процесс образования центров. Напротив, в кварце группы "А" диффузия ионов-компенсаторов затруднена, и процесс формирования парамагнитных центров описывается реакцией, ограниченной диффузией. Второй случай может реализовываться в тех образцах, где состояние структурных каналов не обеспечивает условий для свободной миграции диффузии $\mathrm{Li}^{+}$, т.е. в дефектном кварце.

Данный вывод согласуется с положением точек на графике фиг. 6. В его левой части располагаются точки, отвечающие кварцу месторождения Талатуй, который принадлежит группе “U” и имеет низкую дефектность. Правая же часть соответствует образцам более дефектного кварца месторождений Теремкинское и Дарасун, относящегося к группе “А”.

В том же порядке расположены точки, описывающие образцы с известной принадлежностью к группам “U” или "А”. Действительно, точки U1, U2, U3 и U4 располагаются в левой части графика, а точки A5, А6 и А7 - в правой.
Можно выделить условную границу, разделяющую образцы групп "U” и “A” на графике фиг. 6. Ей отвечает интервал значений отношения $C_{\mathrm{Al}-\mathrm{X}} / C_{\mathrm{Al}}$, приблизительно равный 0.04-0.1. Точки, расположенные внутри этого интервала, следует считать пограничными между группами "U" и "А".

Влияние динамической рекристаллизации на состав подвижных ионов-компенсаторов в структурных каналах. Динамическая рекристаллизация кварца способствует уменьшению дефектности и, соответственно, изменению состава подвижных ионов-примесей в структурных каналах. Такой вывод следует из рассмотрения свойств, приобретаемых кварцем в процессе динамической рекристаллизации.

В самом деле, наличие зон разной дефектности обусловливает неравномерность распределения в кварце ионов-компенсаторов. Наибольшая часть ионов $\mathrm{H}^{+}$содержится в областях слабо упорядоченной кристаллической структуры, где они имеют возможность локализоваться на многочисленных структурных дефектах, имеющих эффективный отрицательный заряд. Ионы $\mathrm{Li}^{+}$в этих зонах в меньшей степени подходят для роли ионов-компенсаторов, поскольку обладают недостаточной диффузионной подвижностью. Обратная ситуация складывается в областях упорядоченной кристаллической структуры. Здесь более конкурентоспособными оказываются ионы $\mathrm{Li}^{+}$, поскольку перенос протонов ограничен.

При динамической рекристаллизации содержание дефектных зон в кварце падает и растет доля областей упорядоченной кристаллической структуры. В соответствии с этим в кварце уменьшается отношение $C_{\mathrm{Ti}(\mathrm{H})} / C_{\mathrm{Ti}(\mathrm{Li})}$. Динамику такого процесса отражает график на фиг. 4, где в качестве показателя динамической рекристаллизации выступает параметр $N_{\text {ті }}$. Эмпирические кривые на графике соответствуют общей тенденции изменения состава ионов-компенсаторов в структурных каналах при динамической рекристаллизации кварца.

Состав ионов-компенсаторов изоморфных ионов $A l^{3+}$. Как говорилось ранее, составы ионовкомпенсаторов изоморфных ионов алюминия и титана могут различаться между собой, т.к. определяются разными стадиями формирования кварца. Если динамическая рекристаллизация кварца проявлена слабо, и его кристаллическая структура дефектна, то состав ионов-компенсаторов изоморфных ионов $\mathrm{Al}^{3+}$ в значительной степени, отражает геохимическую обстановку кристаллизации кварца. Действительно, ионы-компенсаторы $\mathrm{Li}^{+}$в $\mathrm{Na}^{+}$, захваченные изоморфными ионами $\mathrm{Al}^{3+}$ при кристаллизации, могут сохраняться, т. к. процессы их диффузии в дефектном кварце ограничены. Первоначальное положение 
в структурных каналах могут сохранять и протоны, поскольку для образования Al-O--центров требуется достаточно сильное радиационное воздействие на кварц. Из сказанного следует, что ионы-компенсаторы изоморфных ионов $\mathrm{Al}^{3+}$, хотя и расположены в структурных каналах, но обладают меньшей подвижностью и способны нести важную генетическую информацию. Оценить ее значение позволят более детальные исследования.

Многофакторность проиессов, протекаюuих в кварие. При рассмотрении графиков, иллюстрирующих результаты исследований, нельзя не заметить большой разброс экспериментальных точек относительно линий тренда (фиг. 4, 6 и 7). Его причиной является зависимость изучаемых процессов в кварце от нескольких факторов.

Во-первых, изменение состава подвижных ионов-компенсаторов в кварце зависит не только от степени его динамической рекристаллизации, но и от степени открытости-закрытости области рудоформирования. Согласно результатам работы (Гетманская, Раков, 1998), порядок расположения кривых зависимостей $C_{\mathrm{Ti}(\mathrm{H})} / C_{\mathrm{Ti}(\mathrm{Li})}$ от $N_{\mathrm{Ti}}$ на фиг. 4 свидетельствует о росте относительной закрытости областей рудообразующей системы при переходе от месторождения Талатуй к месторождению Теремкинское и далее к месторождению Дарасун. Поэтому график зависимости $C_{\mathrm{Ti}(\mathrm{H})} / C_{\mathrm{Ti}(\mathrm{Li})}\left(N_{\mathrm{Ti}}\right)$ состоит из трех независимых кривых. K тому же в пределах одного месторождения разные участки могут отличаться по степени открытости-закрытости, что еще больше увеличивает разброс точек на графике фиг. 4.

Во-вторых, по крайней мере, два фактора оказывают влияние и на скорость накопления

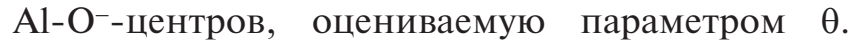
Одним из них является степень дефектности кварца, связь с которой иллюстрирует график зависимости $\theta\left(C_{\mathrm{Al}-\mathrm{X}} / C_{\mathrm{Al}}\right)$ (фиг. 6). В качестве другого фактора выступает содержание изоморфного алюминия $N_{\mathrm{Al}}$, зависимость от которого демонстрирует график $\theta\left(N_{\mathrm{Al}}\right)$ на фиг. 7. Одновременное влияние этих факторов на $\theta$ приводит к разбросу точек на обоих графиках. Некоторым исключением является поведение величины $\theta$ в образцах кварца месторождения Талатуй. Для них отношение $C_{\mathrm{Al}-\mathrm{X}} / C_{\mathrm{Al}}$ принимает постоянное значение, близкое к нулю, и скорость образования $\mathrm{Al}-\mathrm{O}^{-}$-центров начинает определяться только величиной $N_{\mathrm{Al}}$. В этих условиях разброс точек на графике $\theta\left(N_{\mathrm{Al}}\right)$ заметно снижается (фиг. 7а).

Несмотря на многофакторность исследованных процессов, анализ полученных результатов позволяет выявлять основные закономерности их развития.

Сравнение содержаний протонов в исследуемых образиах квариа. Полученные данные дают возможность провести сравнительный анализ концентраций ионов $\mathrm{H}^{+}$в кварце разных месторождений Дарасунского рудного поля. Предпосылкой для этого является взаимосвязь содержания лития $\left(N_{\mathrm{Li}}\right)$ в кварце с содержанием изоморфного алюминия (Ставров и др., 1978; Iwasaki et al., 1991; Федющенко, 2004). Известно, что она носит линейный характер и отражает собой преобладающее участие ионов $\mathrm{Li}^{+}$в компенсации электрического заряда изоморфных ионов $\mathrm{Al}^{3+}$. Исходя из вышеизложенного, отношения значений $N_{\mathrm{Li}}$ в кварце разных месторождений в грубом приближении можно считать равными отношениям $N_{\mathrm{Al}}$.

Тогда при справедливости равенства $N_{\mathrm{H}} / N_{\mathrm{Li}}=$ $=C_{\mathrm{Ti}(\mathrm{H})} / C_{\mathrm{Ti}(\mathrm{Li})}$ для образцов кварца месторождений Дарасун и Талатуй получим следующую систему простых соотношений средних значений:

$$
\begin{aligned}
& \left(N_{\mathrm{H}}\right)^{\text {Дар }} /\left(N_{\mathrm{Li}}\right)^{\text {Дар }}>2.2 \\
& \left(N_{\mathrm{H}}\right)^{\text {Тал }} /\left(N_{\mathrm{Li}}\right)^{\text {Тал }<0.13} \\
& \left(N_{\mathrm{Li}}\right)^{\text {Тал }} /\left(N_{\mathrm{Li}}\right)^{\text {Дар }} \approx\left(N_{\mathrm{Al}}\right)^{\text {Тал }} /\left(N_{\mathrm{Al}}\right)^{\text {Дар }}=2.5
\end{aligned}
$$

Здесь верхние индексы “Дар" и “Тал” означают, что параметр относится к кварцу месторождения Дарасун или Талатуй, соответственно. При составлении соотношений использовались средние значения $C_{\mathrm{Ti}(\mathrm{H})} / C_{\mathrm{Ti}(\mathrm{Li})}$ и $N_{\mathrm{Al}}$ для месторождений, взятые из табл. 4.

Решая данную систему, получим: $\left(N_{\mathrm{H}}\right)^{\text {Дар }}$ / $\left(N_{\mathrm{H}}\right)^{\text {Тал }} \geq 7$. Следовательно, в кварце месторождения Дарасун содержание протонов в среднем в 7 раз превышает их концентрацию в кварце месторождения Талатуй.

Аналогично можно провести сравнение значений $N_{\mathrm{H}}$ в кварце месторождений Теремкинское и Талатуй. Оно показывает, что в первом из них содержание протонов в 3 раза больше, чем во втором.

Таким образом, в кварце месторождений Талатуй, Теремкинское и Дарасун концентрации ионов $\mathrm{H}^{+}$соотносятся как $1: 3: 7$.

Протоны в кварие - индикатор перемещения газовой фазы флюида. Различные концентрации ионов $\mathrm{H}^{+}$в кварце рудных месторождений являются свидетельством разной степени закрытости их минералообразующих систем (Гетманская, Раков, 1998). Однако если эти месторождения формируют единую рудообразующую систему, то различия в концентрациях ионов $\mathrm{H}^{+}$могут указывать на перемещение газовой фазы флюида в процессе рудоформирования.

По всей видимости, высокие содержания $\mathrm{H}^{+}$ в кварце месторождения Дарасун и, в меньшей степени, месторождения Теремкинское связаны с перемещением газовой фазы, образующейся при кипении флюида и обогащенной кислотными компонентами, от высокотемпературной 
области рудообразующей системы к областям с более низкой температурой. Содержащиеся в газовой фазе протоны в ходе гидротермального процесса проникали в структуру кварца и в последующем играли роль ионов-компенсаторов. Заключительная низкотемпературная динамическая рекристаллизация кварца по механизмам BLG и SGR на месторождениях Дарасун и Теремкинское не привела к полному вытеснению ионов $\mathrm{H}^{+}$из минерала, и их присутствие является важным типоморфным признаком кварца.

Таким образом, в качестве индикатора путей миграции газовой фазы на месторождениях Дарасунского рудного поля может быть использовано отношение $C_{\mathrm{Ti}(\mathrm{H})} / C_{\mathrm{Ti}(\mathrm{Li})}$ в кварце. При этом газовая фаза мигрирует из относительно открытых областей рудообразующей системы в относительно закрытые, где ионы $\mathrm{H}^{+}$могут накапливаться в кварце.

\section{ВЫВОДЫ}

1. На примере кварца месторождений золота Дарасунского рудного поля показано, что состав ионов-компенсаторов в структурных каналах зависит от степени дефектности кварца, приобретенной им в процессе минералообразования. Для кварца высокой дефектности основными ионами-компенсаторами являются $\mathrm{H}^{+}$, а для кварца с упорядоченной кристаллической структурой - ионы $\mathrm{Li}^{+}$. Внедрение ионов лития в структурные каналы осуществляется при повышенных температурах в процессе динамической рекристаллизации кварца.

2. Степень дефектности кварца Дарасунского рудного поля определяется интенсивностью его динамической рекристаллизации. По данным исследований методом РЭМ, уровень воздействия динамической рекристаллизации на кварц разных месторождений неодинаков. Кварц месторождений Дарасун и Теремкинское претерпел начальные стадии рекристаллизации при температурах $250-500^{\circ} \mathrm{C}$ по механизмам BLG и SGR, a динамическая рекристаллизация кварца месторождения Талатуй достигает конечной стадии, протекающей при температурах выше $500{ }^{\circ} \mathrm{C}$ по механизму GBM. Выявлен новый признак динамической рекристаллизации кварца по механизму GBM, обнаруживаемый после травления кварца в НF.

3. Доминирующая роль ионов $\mathrm{H}^{+}$в качестве ионов-компенсаторов в дефектных областях обусловлена их высокой подвижностью. Как установлено, скорость диффузии протонов на 1-2 порядка выше, чем у щелочных ионов $\mathrm{Li}^{+}$ или $\mathrm{Na}^{+}$. Столь большая разница в диффузионных свойствах может быть объяснена высокой скоростью переноса протонов по механизму прыжковой диффузии по структурным дефектам, локализованным в зонах слабо упорядоченной кристаллической структуры. Диффузионная подвижность ионов $\mathrm{Li}^{+}$и $\mathrm{Na}^{+}$, наоборот, уменьшается с повышением дефектности кварца.

4. Аномально высокая скорость диффузии ионов $\mathrm{H}^{+}$определяет возможность использования их распределения в кварце для оценки степени закрытости систем минералообразования. Для случая Дарасунского рудного поля показано, что протоны в кварце могут служить индикатором перемешения газовой кислотной фазы флюида при формировании рудообразующих систем. Картина распределения приобретенных ионов $\mathrm{H}^{+}$в кварце может сохраняться после динамической рекристаллизации его по механизмам BLG и SGR. Однако рекристаллизация по механизму GBM вызывает массированный отток протонов из кварца и в значительной мере “стирает” информацию о миграции газовой фазы флюида.

5. Метод ЭПР может использоваться для полуколичественной оценки степени динамической рекристаллизации кварца. Ее проведение предполагает применение разных парамагнитных центров в кварце, что повышает надежность оценки и позволяет обнаруживать динамическую рекристаллизацию на всех стадиях ее проявления.

6. Показано, что образцы кварца групп "U" и "А" отличаются по степени дефектности, обусловленной их разной динамической рекристаллизацией. Принадлежность к какой-либо из указанных групп представляет собой важную типоморфную характеристику кварца, определяющую его генетические свойства.

\section{БЛАГОДАРНОСТИ}

Исследования проведены в рамках тематического плана НИР ИГЕМ РАН “Типоморфные характеристики рудообразующих систем магматогенных месторождений в геолого-тектонических обстановках с многометальной специализацией ( $\mathrm{Au}, \mathrm{Ag}-\mathrm{Cu}, \mathrm{Pb}, \mathrm{Zn}-\mathrm{Mo}, \mathrm{Sn}, \mathrm{W}, \mathrm{TR})$ " № 0136-2018-0023 при финансовой поддержке Российского фонда фундаментальных исследований (проекты № 16-05-00622, № 17-05-00387, № 18-05-00673 и № 19-05-00476).

\section{СПИСОК ЛИТЕРАТУРЫ}

Бершов Л.В., Крылова М.Д., Сперанский А.В. Электронно-дырочные центры $\mathrm{O}^{-}-\mathrm{Al}^{3+}$ и $\mathrm{Ti}^{3+}$ в кварце как показатель температурных условий регионального метаморфизма // Изв. АН СССР. Сер. геол. 1975. № 10. C. 113-117.

Бетехтин А.Г. Минералогия. М.: Госгеолиздат, 1950. Борисенко A.C. Изучение солевого состава газово- 
жидких включений в минералах методом криометрии // Геология и геофизика. 1977. № 8. С. 16-27.

Верти, Д., Болтон Д. Теория и практические приложения метода ЭПР. М.: Мир, 1975.

Гетманская Т.И., Раков Л.Т. Закономерности распределения парамагнитных центров в кварце вольфрамовых месторождений грейзеновой формации // Геохимия. 1998. № 5. С. 539-542.

Кряжев С.Г., Прокофьев В.Ю., Васюта Ю.В. Использование метода ICP-MS при анализе состава рудообразующих флюидов // Вестник МГУ. Серия 4. Геология. 2006. № 4. С. 30-36.

Методические рекомендации. Экспрессное определение методом ЭПР содержаний изоморфных примесей в образцах кварцевого сырья. Раков Л.Т., Миловидова Н.Д., Моисеев Б.М. М.: ВИМС, 1991.

Прокофьев В.Ю., Зорина Л.Д. Флюидный режим Дарасунской рудно-магматической системы (Восточное Забайкалье) по данным исследования флюидных включений // Геология и геофизика. 1996. Т. 37. № 5. C. 50-61.

Прокофьев В.Ю., Бортников Н.С., Зорина Л.Д., Куликова З.И., Матель Н.Л., Колпакова Н.Н., Ильина Г.Ф. Генетические особенности золото-сульфидного месторождения Дарасун (Восточное Забайкалье, Россия) // Геология руд. месторождений. 2000. Т. 42. № 6. С. 526-548.

Прокофьев В.Ю, Зорина Л.Д., Бакшеев И.А., Плотинская О.Ю., Кудрявцева О.Е., Ииков Ю.М. Состав минералов и условия формирования руд Теремкинского месторождения золота (Восточное Забайкалье, Россия) // Геология руд. месторождений. 2004. T. 46. № 5. C. 385-406.

Прокофьев В.Ю., Зорина Л.Д., Коваленкер В.А., Акинфиев Н.Н., Бакшеев И.А., Краснов А.Н., Юргенсон Г.А., Трубкин Н.В. Состав, условия формирования руд и генезис месторождения золота Талатуй (Восточное Забайкалье, Россия) // Геология руд. месторождений. 2007. Т. 49. № 1. С. 37-76.

Прокофьев В.Ю., Бортников Н.С., Волков А.В., Бакшеев И.А., Зорина Л.Д. Вкрапленные руды месторождения золота Дарасун (Восточное Забайкалье) и их генезис // Доклады АН. 2008. Т. 422. № 2. С. 214-217.

Раков Л.T. Стабилизация парамагнитных центров в кварце в природных условиях // Геохимия. 1992. № 10. С. 1488-1492.

Раков Л.Т. Радиационные свойства структурных дефектов в кварце // Геохимия. 1997. № 6. С. 637-643.

Раков Л.Т. Физические аспекты низкодозного определения содержания структурного Al в кварце // Геохимия. 1999. № 9. С. 1016-1021.

Раков Л.Т. Природные и искусственно стимулированные радиационные процессы в кварце: сходство и различия // Геохимия. 2003. № 7. С. 773-784.

Раков Л.Т. Общие закономерности образования структурных дефектов в кварце // Геохимия. 2005. № 11. С. 1196-1207.

Раков Л.Т. Механизмы изоморфизма в кварце // Геохимия. 2006. № 10. С. 1085-1096.
Раков Л.Т. Научные основы применения структурных дефектов в кварце в качестве индикатора минералообразования: Автореф. дис. ...д-ра геол.-мин. наук. М.: ВИМС, 2007.

Раков Л.Т., Моисеев Б.М. Палеодозиметрические свойства Ті-центров в кварце // Геохимия. 1992. № 1 C. $150-154$.

Раков Л.Т., Шурига Т.Н. Структурно-динамическое состояние как генетический критерий кварца // Геохимия. 2009. № 10. С. 1086-1102.

Раков Л.Т., Щипцов В.В., Дубинчук В.Т., Скамницкая Л.С. Кварцевое сырье Карело-Кольского региона: о природе образования и генетическом значении субмикроскопических структурных неоднородностей в кварце // Труды Карельского научного центра РАН. Серия Геология докембрия. Петрозаводск 2015. № 7. C. $164-180$

Раков Л.Т., Дубинчук В.Т., Скамницкая Л.С., Щипцов В.В. Подвижные примеси в кварце Карело-Кольского региона // Труды Карельского научного центра РАН. Серия Геология докембрия. Петрозаводск 2016. № 10. С. $100-118$.

Раков Л.Т., Прокофьев В.Ю., Зорина Л.Д. Элементы-примеси в кварце месторождений золота Дарасунского рудного поля (Восточное Забайкалье, Россия): данные электронного парамагнитного резонанса // Геология руд. месторождений. 2019. Т. 61. № 2.

Самойлович М.И., Цинобер Л.Т., Хаджи В.Е., Гордиенко Л.А. О радиационно-стимулированной диффузии щелочных ионов и протонов в кварце // Кристаллография. 1972. Т. 17. № 1. С. 184-188.

Справочник химика / под ред. Б.П. Никольского М-Л.: Химия, 1982. Т. 1.

Ставров О.Д., Моисеев Б.М., Раков Л.Т. Исследование зависимости между концентрациями алюминиевых центров и содержанием в природных кварцах щелочных элементов // Геохимия. 1978. № 3. С. 333-339. Тимофеевский Д.А. Геология и минералогия Дарасунского золоторудного региона. М.: Недра, 1972.

Федющенко C.В. Структурные примеси в промышленном жильном кварце и породообразующем кварце гранитоидов. Дис. ... к-та геол.-мин. наук. М.: МГУ, 2004.

Урицкий М.З., Цидильковский В.И. Роль акцепторной примеси в переносе протонов в протонпроводящих оксидах // ФТТ. 2014. Т. 56. Вып. 11. С. 2104-2110. Чернышев И.В., Прокофьев В.Ю., Бортников Н.С., Чугаев А.В., Гольиман Ю.В., Лебедев В.А., Ларионова Ю.О., Зорина Л.Д. Возраст гранодиорит-порфиров и березитов Дарасунского золоторудного поля (Восточное Забайкалье, Россия) // Геология руд. месторождений. 2014. Т. 56. № 1. С. 3-18.

Bodnar R. J., Vityk M.O. Interpretation of microthermometric data for $\mathrm{H}_{2} \mathrm{O}-\mathrm{NaCl}$ fluid inclusions // Fluid inclusions in minerals: methods and applications. Pontignano: Siena, 1994. P. 117-130.

Brown P. FLINCOR: a computer program for the reduction and investigation of fluid inclusion data // Amer. Mineralogist. 1989. Vol. 74. P. 1390-1393. 
De Grotthuss, C.J.T. Sur la décomposition de l'eau et des corps qu'elle tient en dissolution à l'aide de l'électricité galvanique // Ann. Chim. 1806. Vol. 58. P. 54-73.

Hirth $G$., Tullis $J$. Dislocation creep regimes in quartz aggregates // J. of Structural Geology. 1992. Vol. 21. P. 145-159.

Iwasaki H., Iwasaki F., Oliveira V.A.R., Hummel D.C.A., Pasquali M.A., Guzzo P.L., Watanabe N., Suzuki C.S. Impurity content characterization of Brazilian Quartz Lascas // Jpn. J. Appl. Phys. 1991. V. 30. № 7. P. 1489-1495.

Lehmann $G$. The structure of yellow iron centres in quartz // Phys. Status Solidi B.- 1971. - 48. K65-K67.

Mackey J.H. ESR study of impurity-related color centers in germanium-doped quartz // J. Chem. Phys. 1963. Vol. 39. № 1. P. 74-83.

Niederberger A. Updating the size of the proton: small difference big consequence // Optics and Photonics Focus. 2010. Vol. 10. P. 4.
Passchier C.W., Trouw R.A.J. Microtectonics. Berlin. Heidelberg. New York: Springer-Verlag. 1996.

Prokofiev V.Yu., Garofalo P.S., Bortnikov N.S., Kovalenker V.A., Zorina L.D., Grichuk D.V., Selektor S.L. Fluid Inclusion Constraints on the Genesis of Gold in the Darasun District (Eastern Transbaikalia), Russia // Economic Geology. 2010. Vol. 105. № 2. P. 395-416.

Urai J.L., Means W.D., Lister G.S. Dynamic recrystallization of minerals / In: Hobbs B.E., Heard H.C. (Eds.). Mineral and rock deformation: laboratory studies // Geophysical monograph. 1986. Vol. 36. P. 161-199.

Weil J.A. A review of electron spin spectroscopy and its application to the study of paramagnetic defects in crystalline quartz // Physics and Chemistry of Minerals. 1984. 10. P. 149-165.

Wright P.M., Weil J.A., Anderson J.H. Titanium colour centres in rose quartz // Nature. 1963. Vol. 197. P. 246-248.

\title{
COMPENSATING $\mathrm{H}^{+}$AND $\mathrm{Li}^{+}$IONS IN QUARTZ STRUCTURAL CHANNELS OF THE GOLD FIELDS OF DARASUN ORE FIELD (EASTERN TRANSBAIKAL, RUSSIA): ELECTRON PARAMAGNETIC RESONANCE DATA
}

\author{
L. T. Rakov ${ }^{1, *}$, V.Yu.Prokofiev ${ }^{1}$, L.D.Zorina ${ }^{2}$ \\ ${ }^{1}$ Institute of the Geology of Ore Deposits, Petrography, Mineralogy and Geochemistry \\ of the Russian Academy of Sciences \\ Staromonetniy alley, 35, Moscow, 119017, Russia \\ ${ }^{2}$ The A.P. Vinogradov Institute of Geochemistry The Siberian Branch of the Russian Academy of Sciences \\ la Favorsky street, 664033, Irkutsk \\ *E-mail:rakovlt@mail.ru
}

Received: 18.02.2016

Accepted: 17.05.2018

The composition and diffusion mobility of the compensating ions in the quartz structural channels of the gold fields in the Darasun, Teremkinskoye, and Talatuy gold fields of the Darasun ore field were examined using the electron paramagnetic resonance method. The assessment of the properties and peculiarities of the ion distribution in quartz was based on their ability to participate in the neutralization of the electric charges of the structural defects occurring in the minerals. In this regard, the ion composition was evaluated by the ratio of the concentrations of the Ti-centers using various compensators. Their mobility was determined by the center formation rate during the quartz radiation exposure. The research demonstrated the availability of two major compensating ions, $\mathrm{H}^{+}$and $\mathrm{Li}^{+}$, in the quartz structural channels of the gold fields in the Darasun ore field. The diffusion mobility of the $\mathrm{H}^{+}$ions in the channels was observed to be $1-2$ orders of magnitude higher than that of $\mathrm{Li}^{+}$. The correlation link between the compensating ions in the mineral and fluid compositions was not obtained based on the data analysis. A difference was identified between the ratio of the $\mathrm{H}^{+}$and $\mathrm{Li}^{+}$concentrations in the quartz structural channels of different fields. Further, the highest concentration of $\mathrm{H}^{+}$ions and the lowest concentration of $\mathrm{Li}^{+}$ions were recorded for the quartz in the Darasun field; the inverse correlation was observed for the quartz in the Talatuy field, which can be attributed to the mixing of the fluid gas component during the ore formation process. The electron paramagnetic resonance method can be used for the quantitative assessment of the degree of quartz dynamic recrystallization.

Keywords: Darasun, Teremkinskoye, and Talatuy gold fields of the Darasun ore field, gold quartz, dynamic recrystallization, compensating $\mathrm{H}^{+}$and $\mathrm{Li}^{+}$ions in the quartz structural channels, diffusion mobility, assessment of the mineralogenesis system closure degree, fluid gas acidic phase movement in the process of ore formation, electron paramagnetic resonance (EPR) method 